\title{
3 CASE ONE: A Comparison between Indiana (1907) and Norway (1934)
}

\subsection{Structural Changes and Social Movements in Indiana (1907)}

The turn of the century brought the United States of America face to face with contradictory social and political tensions. Side by side with the growing power of monopolies were growing demands from progressive political quarters for state and federal government to intervene in the care of the poor, insane and unhealthy as well as to ensure clean food and water, in short, for the beginnings of a "welfare state." Equality and egalitarianism, twin political themes in the United States since colonial times, were now being voiced as demands for equality for women.

The population of the then 46 states was expected to be approximately 46 million in 1900. That year the country also had 8,000 automobiles but only 10 miles of paved road; this would change drastically within a very short time. Life expectancy was 47.3 for white females, 46.3 for white males and 33.0 for all African-Americans. The average weekly wage for workers, many of whom had just immigrated from Eastern Europe and Ireland, was $\$ 12.98$ for 59 hours of work ${ }^{128}$; child labor laws and protective legislation for women workers were extremely controversial. But "progressive" forces were at work in the United States and during 1906, the first state and federal Food and Drug Act was passed in the United States as a protective measure against pseudo-medical "quackery." 129

Geographically, Indiana - the "Hoosier state" - is located directly south of one of the Great Lakes, Lake Michigan. ${ }^{130}$ At the western intersection of Indiana with Lake Michigan, Gary Indiana now joins the suburbs of Chicago, Illinois to create a major metropolitan area. On 11 December 1816, Indiana was the 19th state admitted to the federal union. The capitol has been Indianapolis since 1825; Indianapolis is almost in the geographical center of this rectangular state, in Marion County. In 1907 it was the largest city in the state, followed by Fort Wayne in the northeast corner, Evansville in

128 Statistics taken from Kingwood College Library Internet website at http://kclibrary.nhmccd.edu/ decade00.html\#events, accessed on 3 December 2007.

129 The first court trial to be held under the new law began in February 1908. U.S. v. Cuforhedake Brane-Fude. The issue was mislabeling about the contents of this headache remedy.

130 Opinions differ as to the derivation of the word "hoosier." A contractor named Samuel Hoosier, who liked to hire Indianans did exist but the word may also come from the phrases "Who's yer?" or "Who's there?" or "hoozer" a local word for "hill.” All general geographical and geo-political data in this section is taken from Volume 10, The World Book Encyclopedia (Chicago, London, Sydney, Toronto: World Book, Inc., 1993), 196-219 and from http://www.1911encyclopedia.org/Indiana, accessed 9 March 2007. 
the southwest corner, Gary, in the northwest corner, and South Bend on the middle northern border with Michigan. ${ }^{131}$

In 1900, the state had a population of 2,516,462, which rose by approximately 200,000 to $2,700,876$ in 1910 , making it the 9th most populous state in the Union. In 1900, 34.3\% of the state was "urban" where "urban" was defined as cities of 2,500 or more inhabitants. This meant that $65.7 \%$ of the population lived in rural areas, dropping by $7.4 \%$ in just ten years from $73.1 \%$ in $1890 .{ }^{132}$ By $1920,50.6 \%$ of the state's population would live in urban areas; in just 30 years $25 \%$ of those who had been living in rural areas were relocated with a corresponding increase in the urban population of about $20 \%$. The five cities that qualified as urban centers in 1900 were Indianapolis $(169,164)$, Evansville $(59,007)$, Fort Wayne $(45,115)$, Terre Haute $(36,673)$ and South Bend $(35,999)$. There were 14 cities with a population range from more than 10,000 to less than 21,000. The foreign born population of Indiana in 1900 was 142,121 or $5.6 \%$ and the African-American population was 57,505 or $2.3 \%$. In 1906 , members of religious congregations were counted. The total numbers of those claiming membership was 938,405 or $37.3 \%$ of the entire population. The three largest Church memberships were Methodists $(233,443)$, Roman Catholics $(174,849)$ and Disciples of Christ $(108,188){ }^{133}$

In $1900,95.1 \%$ of the land area of Indiana was farmland with $28.6 \%$ of this farmed by tenant farmers rather than farm-owners. From 1850 to 1900 , the size of farms steadily decreased from 136.2 acres in 1850 to 105.3 acres in 1880 and 97.4 acres in 1900. Farmers used a three-crop rotation system for their main crops of corn, wheat and hay. In 1907, the Department of Agriculture estimated that Indiana's agricultural acreage was 7 th in the nation for corn $(4,690,000$ acres), 6th for wheat $(2,328,000$ acres) and 8th for hay $(2,328,000)$. Although furnishing about 200,000 officers and soldiers for the Union effort, Indiana saw little actual fighting within the state proper during the Civil War. After the War, farmers were plagued by debt and low prices for their products. This, combined with periodic ecological infestations and high freight prices, made the economics of ante-bellum Indiana troublesome.

In 1906, the United States Steel Corporation began building the city of Gary and erected its largest steel plant there. This was after the Standard Oil Company built one of the world's largest oil refineries in Whiting on Lake Michigan. In 1900, the state had 7,128 manufacturing establishments characterized as "factories"; their invested

131 Today, there are 92 counties in Indiana with 77 legislative districts. In 1907 there were also 92 counties.

132 Justin E. Walsh, The Centennial History of the Indiana General Assembly (1816-1978) (Indianapolis: The Select Committee on the Centennial History of the Indiana General Assembly and The Indiana Historical Bureau, 1987), 287.

133 The remaining Church memberships were Baptist (92,705), Presbyterians $(58,633)$, Lutheran $(55,768)$, United Brethren (52,700) and the German Evangelical Synod (21,624). 
capital was $\$ 219,321,080$. Five years later, that invested capital rose to $\$ 312,071,234$, which was an increase of $42.3 \%$. In the 1880 s the predominant form of transportation was the steam-powered railroad but by 1900 , electric railroads were the main means of intrastate transportation. ${ }^{134}$ In part, the combination of an increase in railroad connections, the discovery of natural gas and the proximity of coalfields made this surge possible. By 1909, Indiana had 7,286 meters ${ }^{135}$ of railway with trunk lines that ensured transportation of products to the burgeoning Midwest industrial centers, such as Chicago. The first Indianapolis 500 automobile race took place in 1911 and demonstrates the surge in car production associated with urbanization and industrialization of life in Indiana's major cities.

The air quality in Indianapolis in 1907 was, if we interpret correctly from a series of cartoons in the Indianapolis News - filthy. On 25 April a large square filled with 10 smaller cartoons bearing the headline "A Simple Sum in Arithmetic" appeared. The top figure showed a series of smoke-belching smokestack followed by a plus sign $(+)$ followed by the Indianapolis Smoke Inspector sitting, smoking a cigar, in a seat surrounded by cobwebs. The balloon coming from the Inspector reads, "There is no preventive for smoke" and this was followed by an equal sign (=). Below this were nine smaller cartoons showing The Indianapolis Collar (dirty), the Indianapolis Skirt (dirty hem), Gloves After an Hour's Wear (dirty), the Indianapolis Desk (dirty), the Indianapolis Face (swirling dirt around it), the Indianapolis Affliction Called Cinderitis (tongs taking a huge cinder from a man's eye), the Indianapolis Apology ("Indianapolis would be all right if it weren't for the smoke"), the Visitor's Comment ("New York wouldn't stand for this smoke nuisance for a minute!”) and an Indianapolis Building at Six Months Old (filthy). ${ }^{136}$

Indiana State was home to a number of social movements at the turn of the century; in many cases these reflected the same movements at a federal level. These included the women's right to vote movement, the prohibition movement, various movements based on interpretations of Social Darwinism and Eugenics, the right to clean food and drink movement, etc. Many of these can be viewed as existing under the umbrella of the "progressive movement." In part, this is due to the fact that the progressive movement in the United States in 1907 included several rhetorical "masterframes" that legitimated different types of social activity by that movement.

While the rhetorical devices that were mentioned above stand as general rhetorical devices, a special vocabulary has been developed for the study of social movements. Rudolf Heberle uses the idea of "constitutive ideas" to mean ideas that are "most essential to a social movement [and] that form the basis of its solidarity and of

134 Walsh, Centennial History, 287.

1354.3 miles.

136 Indianapolis News, 23 April 1907, 3. 
concerted action for the pursuit of common goals." ${ }^{137}$ Much study of the "framing" of issues also exists and has focused on the meso-level, e.g. rhetorical strategies of civil rights movement organizations. ${ }^{138}$ However, such meso-level frames must also resonate with overarching cultural frames, called "masterframes." As Owen Wooley notes "masterframes" are ideas that are "simply collective action frames writ large that are adopted by multiple social movements." 139

The idea of historical masterframes has been seen as a "cultural equivalent to cycles of protest" in the resource mobilization school because they explain the "temporal clustering of movements." 140 Wooley admits the idea has been underutilized because of "theoretical inconsistencies", the main problem being that a clustering of protests is necessary to form a masterframe yet a masterframe is necessary to bring about such a clustering. The answer to this has been to emphasis that masterframes are "cultural codes that movements adopt from external sources" and thereby separating out movements from the larger milieu. ${ }^{141}$ The definition of ideology incorporates the idea of "constitutive ideas", i.e. "masterframes" which allows two further activities - solidarity and activity justification.

The idea of "framing" needs to be discussed here for a moment and distinguished from ideology. While the making of frames indicates an active process of meaning making, ideology can be either a resource or a constraint within collective action frames ("CAF"). Oberschall reviews the literature on ideology for us and points out that Herbert McClosky's 1964 definition of ideology is that it is “'a system of belief that is elaborate, integrated, more or less coherent, which justifies the exercise of power, explains and judges historical events, identifies political rights and wrong, and furnishes guides for action." "142 Philip Converse's definition from the same year uses the term "belief systems" rather than "ideology" to mean a "configuration of ideas and attitudes in which elements are bound together by some form of constraint or functional interdependence'." 143

137 W.A. Gamson, Talking Politics (Cambridge, New York and Melbourne: Cambridge University Press, 1992), 111.

138 Please see, Aldon D.Morris and Carol McChug Mueller (eds.), Frontiers in Social Movement Theory (New Haven and London: Yale University Press, 1992), and Sidney Tarrow, Power in Movement: Social Movements and Contentious Politics (2nd Ed.) (Cambridge: Cambridge University Press, 2006).

139 Owen Wooley, "Locating Masterframes in History: An analysis of the Religious Masterframe of the Abolition Movement and its Influence on Movement Trajectory" in Journal of Historical Sociology, 17 (2004), 493.

$140 \mathrm{Ibid}$. The idea of historical master frames has been seen as a "cultural equivalent to cycles of protest" in the resource mobilization school because they explain the "temporal clustering of movements."

141 Ibid., 494.

142 Anthony Oberschall, Social Conflict and Social Movements (Englewood Cliffs, New Jersey: Prentice Hall, Inc., 1973), 178.

143 Ibid. 
Framing, of course, occurs at all social levels - the macro-, meso-, and micro-levels. In 1907, a number of masterframes supported a feeling of moral panic in societyat-large. What was society to do with poor, uneducated women and children? How could society ensure that these people would have correct morals and maintain the decency expected of them? All of the schemas and resources that were associated with this movement are beyond the scope of this work, but suffice it to say that this movement possessed relatively deep structures that appear to emerge from time to time - for example in the 1960s in the United States.

The progressive movement saw itself as basically reformist in nature and worked in all areas of economic, social and political life. In terms of economic history, we know the United States had experienced an economic depression from 1893 until 1897 and that this depression affected the entire nation. The progressive movement is generally thought to have begun during this period and ended in 1917 with the entry of the nation into World War I. To be sure, some of the goals and methods of the progressive movement produced significant results. But the point to be made here is that its goals and methods often intersected with the eugenics movement itself, and for that matter, the emerging feminist movement.

The discursive work of the progressive movement rested on quite different interpretations of themes and ideas than were in circulation before the financial crises of 2009. ${ }^{144}$ At the turn of the 19th century in the 20th century, the words "liberty" and "freedom" had a certain "outmoded" and "unscientific" salience among the movement. ${ }^{145}$ Civil society had been able, at the turn of the century, to see through cries for "personal freedom" because of the damage done in its name. Society demanded a more paternalistic attitude in government. At exactly the same time, the eugenics movement was gaining momentum and the two merged under some of the same ambiguous ideographs, i.e. "social control” and "individualism.” Martin Barr was an early proponent of the sterilization of the "unfit" and his writings demonstrate the alignment process between of the two movements which allows for frame bridging between movements:

What in the beginning was a philanthropic purpose pure and simple, having as its object the most needy and therefore naturally directed toward paupers and idiots now assumes the proportions of a socialistic reform as a matter of self-preservation, a necessity to preserve the nation from the encroachments of imbecility, of crime, and of all the fateful heredities of a highly nervous age. ${ }^{146}$

144 An extreme capitalism along with an extreme individualism was exported to eastern European countries at the demise of Communism. Some of these countries are beginning to rethink the model. The equation "liberty" = "no rules" is also being rethought, especially by governments vis-à-vis the banking sector.

145 Hasian, The Rhetoric of Eugenics, 26.

146 Ibid., 27. 
What can be noted in this quotation is a frame bridging between the progressive movement and socialism. But this did not ensure that either survived. While the progressive movement went into remission with Great Depression and its contingencies in the United States, the eugenics movement continued through a process of frame transformation aided by the credibility of scientific framers. ${ }^{147}$ This frame transformation continued well into the 1970s, its former moving target - "paupers and idiots" having mutated into "welfare mothers."

Discourses that were embedded in the eugenics movement contributed to the sense of "moral panic" in Indiana in 1907. In order to see how this happened, we return to social movement theory. Sidney Tarrow writes that "collective challenges, based on common purposes and social solidarities, in sustained interaction with elites, opponents and authorities" can be seen in social movements. ${ }^{148}$ I will examine a number of these elites, opponents and authorities below. Tarrow quotes Charles Tilly as saying that:

Authorities and thoughtless historians commonly describe popular contention as disorderly... But the more closely we look at that same contention, the more we discover order. We discover order created by the rooting of collective action in the routines and organization of everyday social life, and by its involvement in a continuous process of signaling, negotiation, and struggle with other parties whose interests the collective action touches."149

One of the simplest examples of the "rooting of collective action in the routines and organization of everyday social life" is seen when we examine the eugenics-inspired "Better-Baby" contests held around the United States at this time. One such Better Baby Contest was held in Indiana in 1906. These better baby contests, part of the routine of everyday life in Indiana, are an example of what has been later referred to as "positive" eugenics. Such a harmless daily activity in a society under stress, even at the micro-level, cannot be ignored. Through the mere naming of them as "Better Baby Contests", and relegating them to the domestic realm, it was possible to overlook their power. ${ }^{150}$ But the rhetorical naming of them as "Better Baby Contests" signifies gradation of worth and they worked to advance both progressive and eugenics ideas, even if at a micro-level. ${ }^{151}$

147 The diagnostic variety of an "injustice frame" is never fully eliminated, however, and still retains a resonance in the United States, resurfacing again in the 1960s.

148 Sidney Tarrow, Power in Movement, 4. Note 333.

149 Charles Tilly, The Contentious French (Cambridge, Massachusetts: Harvard University Press, 1986), 4. (Emphasis mine.)

150 Please see Martin S. Pernick, M.D., “Taking Better Baby Contests Seriously” (Editorial), in the American Journal of Public Health, 92 (2002), 707-708.

151 I am not questioning the fact that some babies have, for example, redder hair than others, only that the standards by which "better" is judged need to be closely examined. 
Alexandra Minna Stern has examined the records of the Committee on Mental Defectives, begun in Indiana in 1915 by then Governor Samuel Ralston as well as other records reaching in to the 1950s and found that in 1920, the eugenics movement in Indiana was "thriving." 152 She found that:

Gauged in terms of the involvement of state leaders and agencies 1910 to 1930 was the zenith of Hoosier eugenics. However, hereditarian ideas started to reverberate across Indiana in the 1880s and justification for sterilization based on inferior genetic worth did not dissipate until the 1950 s. ${ }^{153}$

Although 1910 to 1915 may have been the "zenith" for the eugenics movement in Indiana, the movement continued and Stern reports that between 1929 and 1974, about 2,000 inmates of the Indiana state institutions - for the feebleminded, insane, epileptic, and delinquent - were forcibly sterilized. ${ }^{154}$ This substantiates the evidence found by Allison Carey who has researched the continued use of forcible sterilization of women into and beyond the 1950s. ${ }^{155}$

Indiana also had a direct connection inside the Cold Spring Harbor laboratory, which, a this time, was the eugenics "hub" in the United States. In early April, the News printed an extensive story on the work being conducted at the Carnegie Institute in Washington, D.C. A “Professor Davenport”, most likely Charles B. Davenport, was quoted as saying that the work being done there "points a way - a new way - to the improvement of the human race.” Davenport's remarks, if they were remarks and not meant as text, were quoted extensively and addressed the discoveries of Mendel. Davenport discussed the work of the Cold Spring Harbor Station, especially the experiments with poultry. ${ }^{156}$ And, one of the scientists working with Davenport at Cold Spring Harbor was Prof. W.J. Moenkhaus of Indiana University. ${ }^{157}$

152 Alexandra Minna Stern, "We Cannot Make a Silk Purse out of a Sow's Ear": Eugenics in the Hoosier Heartland, 1900-1960" in Indiana Magazine of History, 107 (2007), 20.

153 Ibid., p. 27. I disagree with Stern that the "inferior genetic worth" masterframe dissipated in the 1950s and would suggest it merely "morphed", or lay dormant until another opportunity arose for it to again gain momentum. Please see the works of Troy Duster, "Lessons from History: Why Race and Ethnicity Have Played a Major Role in Biomedical Research" in Journal of Law, Medicine and Ethics, 34 (2006), 489.

154 Ibid., 20.

155 Allison C. Carey, “Gender and Compulsory Sterilization, 74-105. Note 208.

156 In 1910, Davenport would become the head of the Eugenics Records Office "ERO" at the Cold Spring Harbor facility. The founding of this office came from the widow of railroad magnate, E.H. Harriman. Mrs. E.H. Harriman, whose daughter Mary had spent the summer of 1905 at the Cold Spring Biological Station as an undergraduate from Barnard College, agreed in 1910 to help finance the ERO. The work of the ERO was also assisted by funding from John D. Rockefeller, Jr. Please see Kevles, Name of Eugenics, 54-55.

157 "Evolution Tests At Carnegie's Expense. Interesting Experiments at Cold Spring Harbor. Possibility of New Race?" Indianapolis News, April 5, 1907, 8. 


\subsection{Welfare Institutions and Political Governance in Indiana}

State government, pursuant to the 1851 Constitution, included a Governor, for a fouryear term plus a bi-cameral General Assembly consisting of 50 Senators, at least 25 years of age with 4-year terms and 100 Representatives, at least 21 years of age with 2-year terms. From 1897 through 1909, the state elected three Republican governors in succession: James A Mount (s. 1897-1901), Winfield T. Durbin (s. 1901-1905) and J. Frank Hanley (s. 1905-1908). ${ }^{158}$ After Governor Hanley's administration, during which the world's first coercive sterilization law was passed, two Democrats were then elected in succession, Thomas R. Marshall (s. 1909-1912) and Samuel M. Ralston (s. 1913-1916).

In 1907, Indiana, like others states, had a number of prisons. "Far-reaching" reforms had been made in the prison system in 1897 under the Republican governorship of James Atwell Mount (1843-1901), elected in 1896. The General Assembly had passed an indeterminate sentence and parole law, which had been recommended two years earlier by a legislatively sponsored commission. ${ }^{159}$ This penal scheme allowed for the release of male prisoners older than 16 years of age who had been convicted of a felony and had served their minimum sentence. Excluded from release were men convicted of murder or treason; later excluded were those convicted of a third felony or of the rape of child less than 12 years of age. Some saw this law as a "coddling” of the criminal element but, after the Indiana Supreme Court upheld its constitutionality in 1898 , this outcry lessened. ${ }^{160}$ In 1898 , the same penal scheme was applied to women prisoners 18 years of age or older. A Parole Board was set up to decide on releases and for the one-year supervision following release. During Governor Hanley's administration, in 1907, the General Assembly also authorized circuit and criminal court judges to suspend the sentences of persons convicted of some crimes, both felonies and misdemeanors, and to be placed under supervision, a form of probation or parole. From April 1, 1897 to September 30, 1915, approximately 9,338 prisoners were paroled with 5,685 or $61 \%$ successfully completing the following year of supervision. ${ }^{161}$

In 1900, the state had five penal institutions. These were the Indiana Boys' School, opened in 1868 and known by various names thereafter such as the Plainfield School. Other penal institutions included the Indiana Girls' School (1873), opened in Indianapolis and then moved to Clermont in 1907, a Women's Prison (1873) - the first in the United States. Other penal institutions included a Reformatory using the "Elmira Plan" opened in 1897, a State Prison South (Jeffersonville), opened in 1860,

158 My notation "s" indicates the dates that the person served in office during the indicated dates. 159 Clifton J. Phillips, vol. IV of Indiana in Transition: The Emergence of an Industrial Commonwealth, 1880-1920 (Indianapolis: Indiana Historical Bureau and Indiana Historical Society, 1968), 490.

160 Ibid.

161 Ibid., 491. The failure rate is given as $26.9 \%$ and no explanation is given for the remainder. 
and a State Prison North (Michigan City) opened the same year. ${ }^{162}$ These individual state institutions were under the control of a separate bi-partisan board of four members.

The entire state system of public charity was also under a similar system, the Indiana State Board of State Charities (1889) (ISBC), in which the Governor appointed all four members. Complementing this system at the county level were unsalaried boards of county charities and correction and county boards of children's guardian, appointed by circuit court judges. A total of 1,016 township trustees in Indiana were overseers of the poor and were the authorities who dispensed official relief. Each county provided for the indoor care of the poor in poor asylums and children's homes as well as for prisoners in county jails. A child could be made a ward of state only by Juvenile Court order; these children were then place into other homes by agents of the above Board of State Charities.

In general, institutional composition as well as their placement and goals were in a state of flux in Indiana, as well as elsewhere around the United States. An example of this was the establishment in Indiana in 1915 of the Indiana State Farm in Putnamville for male misdemeanants, 16 years or older, mentioned above. Legislative thinking was that these persons could serve their time in a "healthful, unprisonlike surroundings" rather than in a county jail, where they might be exposed to older, "hardened" criminals. ${ }^{163}$ Indeed, within the first year of the opening of Putnamville, 1,174 prisoners from 73 of Indiana's 90 county jails were transferred there. ${ }^{164}$ Convict labor was also present in Indiana and was called one of its "thorniest" problems. ${ }^{165}$

Aside from state institutions that dealt with the criminal, poor and juvenile populations, several state and private charitable institutions were also established by 1906. Indeed, they had largely been established between 1820 and 1840, the "age of the asylum", according to historian David J. Rothman. ${ }^{166}$ An Institution for the Education of the Deaf was established in 1844 and an Institution for the blind in 1847, both located in Indianapolis and both being two of the first such institutions in the Union. Additionally a State Hospital for the Insane was opened in 1848 (Indianapolis), all three touted as legislative "showcases." At that time the legislature was "reeling from the collapse of the internal improvements system" and needed to show also that its "representative government could operate in an enlightened, progressive way" since, until the 1840s, Indiana had "lagged behind" many other states in its responsibili-

162 Walsh at p. 251 indicates that the Jeffersonville Prison was opened in 1821 but because of its sanitary conditions, medical problems (typhus and scurvy) and overcrowding, the Michigan City prison was legislatively mandated in 1859.

163 Ibid., 491-92.

164 Ibid.

165 Ibid., 493.

166 Walsh, Centennial History, 105; and David J. Rothman, The Discovery of the Asylum: Social Order and Disorder in the New Republic (Boston: Little, Brown \& Co., 1971), XIV. 
ties to the disenfranchised. ${ }^{167}$ In 1844 , then Governor James Whitcomb was fortunate to have Democrats in charge of the General Assembly who voted to establish and to finance these institutions.

A "second wave" of institution building - in the sense of both infrastructure and social institutional structures - began after the Civil War. The Northern Indiana Hospital was established in 1888 (Logansport), the Eastern Indiana Hospital in 1890 (Richmond), the Southern Indiana Hospital in 1890 (Evansville) and the South-Eastern Indiana Hospital in 1905 (Madison). A Soldiers' and Sailors' Orphans' Home was opened in 1868 (Knightstown Springs, Rush County) ${ }^{168}$, a State Soldiers' Home in 1896 (Lafayette), a School for the Feeble-Minded Youth in 1879 in Knightstown and then moved to Fort Wayne in $1890^{169}$, a village for epileptics in 1907 (New Castle) and one hospital for the treatment of tuberculosis to be built in Rockville, which was authorized in 1907 and the land for which was purchased in 1908. A series of scandals in the late 1880s at the Knightstown Orphans' Hospital (1885), the State Prison South (1885) and the Insane Hospital in Indianapolis (1887) brought more reforms. At the orphanage "pederasty and child abuse" were alleged, at the prison, "sadism and repeated cruelty" were alleged and at the insane asylum, charges of "nepotism, cruelty, extortion and graft" were said to have created a situation where patients "were fed maggoty butter, and pork from a drove of hogs dying of cholera..."170

As can be seen from this brief introduction, Indiana was changing in terms of both its population and its economic profile. In response to this and other macrophenomena, a social panic developed. One of the ways in which this panic was manifested was in the idea of "race suicide." This idea was everyday fare in many newspapers and asserted an ideograph. This ideograph was a discursive unit that warranted that the population of the "right" type of Americans was decreasing. Rich, white, and educated women were often the focus of this argument since it was they who were not having enough children. Poor, immigrant and uneducated women where, on the other hand, having all too many children. As with panic in general, the targets became more and more plentiful so as to accommodate the rhetorical label of “degenerate."

Ideas about the degeneration of the population were also fueled by some social scientists who, with concepts of Darwinian social evolution, sought to influence public policy. Not only were there "scientific" data that could be used by legislatures to support this social Darwinism but, at the very same time, the legal profession of the United States was also undergoing a significant change in the way in which law

167 Ibid., $105-106$.

168 Walsh at p. 251 gives 1867 as the date for establishment of this institution.

169 Walsh at p. 251 gives 1887 as the date for its removal to Fort Wayne.

170 Walsh, Centennial History, 252. 
was taught, supposedly patterned after the natural sciences. ${ }^{171}$ Law was advocated as a science similar to physics, chemistry or biology. And legislation became one of the sites of social and cultural contestation.

In the end, Indiana was perceived by many national groups as accomplishing a great deal of good in terms of social welfare issues. On June 12-13, 1907, Minneapolis Minnesota hosted the 13th annual meeting of the National Conference of Charities. Indianan Dr. Amos Butler would give the President's address to this meeting with Indiana's Senator Beveridge to follow. This was an indication of how important the "Indiana way" was, and how it had gained momentum throughout the United States as well as within the progressive movement itself. ${ }^{172}$ But the "Indiana way" didn't end with charitable works that left the beneficiary's body intact. Indiana's own Dr. H. Sharp's development and use of the vasectomy on prisoners, his own form of the "Indiana Plan", soon became a model for compulsory sterilization as well as creating the legislation and institutional practice in a number of states "for many years to come."173

\subsection{Scientific Discourses and "Race Suicide" in Indiana}

While the presence of societal problems and the disarticulation/rearticulation of large-scale societal ways of living are significant, it is only part of the puzzle of law formation at this time. The other half is norm production, its life cycle and denouement or subaltern hibernation. If we refer back to the two norm theories discussed in Chapter 1, we see that at the "micro-objective" level of Rickert's model, he includes "patterns of behavior, action and interaction" while at his "micro-subjective" level, he includes such things as perceptions and beliefs or "the various facets of the social construction of reality." 174 We should remember that, in this theory, these two areas interact continuously with the macro-objective and the macro-subjective.

Before beginning, we should remind ourselves that Darwin's The Origin of Species, published in 1859, was a scientific comet that hit the earth, creating deep, perhaps even permanent, fault lines in some societies and throughout societies' numerous activities, most notably religion. Without that realization, what happened in 1907/1934 would make little sense.

171 Please see Schweber who has written extensively on Christopher Columbus Langdell and development of the "case-law" technique at Yale.

172 Indianapolis News, April 25, 1907, 8.

173 Angela Gugliotta, "Dr. Sharp and His Little Knife: Therapeutic and Punitive Origins of Eugenic Vasectomy - Indiana, 1892-1921” in Journal of the History of Medicine, 2nd Allied Sciences, 53, (1998), 386-87.

174 Please see discussion in Chapter 1. 
The first example is that of the power of institutional science intersecting with the intersubjective categories of gender and of race/ethnicity. In 1904, Republican and committed prohibitionist James Frank Hanley (1863-1920) (s. 1905-1919) defeated the Democratic candidate, John Worth Kern, to became Governor of Indiana. ${ }^{175}$ On the same day as Hanley's inauguration, on the editorial page of the Indianapolis Star was a letter entitled "Race Suicide" by J.A. Houser M.D. He concerned himself with the low birth rate, especially between "highly educated and refined women" that produced only 1 or 2 children. ${ }^{176}$ Houser minced no words, saying of these women that, "Their education and surroundings have developed them into psychic, esthetic, sensitive, nervous creatures, who are women only in name." 177 Not to be considered unscientific however, he resorted to quantification, claiming that men could also become like this, but "only one-sixth as frequently as women." Two examples of this phenomenon in men were Charles Sumner (1811-1874) and Wendell Phillips (1811-1884) who, while having "brain-power" and leaving wisdom in the world, apparently left no offspring. The article was a hazy blend of racism, genetics and evolutionary thought based on Houser's concern that "[o]ur race is passing away."178

A scant two days later was another letter-to-the-editor echoing Dr. Houser's thoughts of the 12th of January with the title "Vitality of the Races in the Light of Science." ${ }^{179}$ Signed only with the name "Flandrau", the letter cites three "authorities" on the subject of race vitality. He began by citing the birth rate statistics, which had been published barely a week earlier as a "confirmation of Frederic L. Hoffman's conclusions regarding of the virility of the two races."180 In Hoffman's book, Race Traits of the American Negro, Hoffman advanced a theory that, prior to emancipation, the "negro presented in many respects an excellent physical type, even superior to the white man" but that after emancipation, they migrated to northern and eastern cities and lived "in the midst of the most unsanitary surroundings and under the most immoral influences" with a higher death rate than for whites. ${ }^{181}$ Hoffman's use of the statistical method is cited with approval by "Flandrau" who went on to say that the "Aryans can not absorb the negroes by amalgamation."

175 Please see Indiana Government website http:/www.in.gov/gov/history/Hanley.html last accessed 11 August 2009.

176 “Race Suicide.”Indianapolis Star, January 12, 1907, 8.

177 Ibid.

178 Ibid.

179 “Vitality of the Races in the Light of Science.” Indianapolis Star, January 14, 1907, 8.

180 Ibid.

181 Frederic L. Hoffman, "Race Traits of the American Negro" in the Publications of the American Economic Association, Vol. XI, Nos. 1, 2, 3. (New York: Macmillian and Co., 1896), 8. Hoffman's book was reviewed by Gary N. Calkins of Columbia University in the Political Science Quarterly, XI (1896), 754-757. 
"Flandrau" also cited James Bryce (1871-1922) as showing there is a "decreasing tendency toward the mixing of the two races, not only in America but also in South Africa.” Mulatto children "are physically and morally inferior to the pure blacks...lose in vitality what they gain in symmetry and intelligence and they die, early." Flandrau ended his letter by citing Frederick Starr (1858-1933), Professor of Ethnology at the University of Chicago ${ }^{182}$, that:

Recognition of difference between white men and black men is fundamental. The desire and effort to turn bright black boys into inefficient white men should cease. It is imperative that we demand honesty toward the Negro and decency for him but we must expect the race here to die and disappear. If the race is capable of adjustment to American surroundings time will solve the difficulty kindly. If not, time will solve the difficulty, but not severely. ${ }^{183}$

Here, we have the work of three men that informs the basis of "Flandrau's" opinions and it is an easy matter to see how they fit into Tarrow's definition of a national social movement as they present discursive "collective challenges, based on common purposes and social solidarities, in sustained interaction with elites, opponents and authorities." 184

Frederick L. Hoffman (1865-1946), whom "Flandrau” also cited in this letter, was a professional statistician who worked for the Prudential Insurance Company in Newark, New Jersey. ${ }^{185}$ The American Economic Association published Hoffman's first book, mentioned above, in 1896. Hoffman's thesis was that the "Negro was susceptible to many illnesses and constitutionally unfit for survival and was destined to die out." ${ }^{86}$ According to Francis Sypher, writing in the conservative Cosmos Club's journal in 2000, Hoffman - a conservative Republican - eventually reversed his opinions, saying that the Negro health was impacted more by environment than by race. ${ }^{187}$

182 Frederick Starr was one of the founding members of The American Breeders Association which itself had a long association with the eugenics movement in the United States.

See also, Starr, “The Degeneracy of the American Negro" in Dial, XXII (1897), 17-18.

183 Hoffman, "Race Traits", Footnote 311.

184 Tarrow, Power in Movement, 4.

185 Please see: http://www.cosmos-club.org/journals/2000/sypher.html, accessed on December 3, 2007. The Cosmos Club calls itself "a private social club" located at 2121 Massachusetts Ave. N.W. in Washington D.C. Although some may dismiss the "grand narrative" style, it is sometimes useful for our historical memory.

186 Francis J. Sypher, “The Rediscovered Prophet: Frederick L. Hoffman (1865-1946)” in George S. Robinson (ed.), The Cosmos Journal, 2000. (No volume or number given.) Sypher notes that Hoffman's treatment of the subject of race saying Hoffman's impulses were "primarily humanitarian" and influenced "by the prevailing racism and Darwinism of the time." The sub-lead to this article reads "Prescient and prolific in his writings, F.L. Hoffman is finding new audiences 50 years after his death." In 1897, Kelly Miller wrote a review of Hoffman's work, criticizing Hoffman's methodology and his use of the 1890 census in Occasional Papers of the American Negro Academy in Washington D.C.

187 Ibid., citing to the New York Times, February 6, 1926. 
However, Beatrix Hoffman has a different conception of Frederick Hoffman from that published in today's The Cosmos Journal. She places him as a "formidable opponent of the emerging welfare state during the Progressive Era”, someone who was a relentless campaigner against "government-run compulsory health insurance between 1915 and 1920." "188 In short, the representations of what science could achieve often promised a scientific solution to the problem of "race suicide."

The micro-subjective discourse level in Indiana also assumed - in the main - that science was benevolent. Members of Indiana's reading public who read the Indianapolis Star had access to various and sundry scientific news in it. In an editorial entitled "Scientific Pleasures", the editor of the Star mentioned how some scientific work was done in the seclusion of a laboratory, citing work done by Koch or Pasteur; their motive was clearly the "welfare of mankind." But there were also scientists-asadventurers such as Professor Agassiz and his party of scientists who were about to travel to the West India Islands to take "deep sea soundings" in connection with a recent earthquake in Jamaica. ${ }^{189}$ The editor editorializes that:

Professor Agassiz and his brethren will enjoy the poetry and romance of science on this tour, and though they will doubtless add to the sum of the world's knowledge they will themselves have gained much more than mere dry scientific data. The best rewards of the best work are not covered by a bank account or measured by public applause. ${ }^{190}$

Whether or not the pursuit of science at this time was so unaffected by financial concerns as this editorial assumes is outside the scope of this discussion. What is not, however, is that it was perceived as such by this man at this time and place and that the "welfare of mankind" was represented as the prime motivation in scientific research.

The second example concerns gender. Gender and race/ethnicity were both affected by discursive narratives, which included the "scientific" idea of "race suicide." The micro-level of society does not get much smaller than the toys our children play with. Yet, even at that level, the idea of "race suicide" intersected with discourses of what a "real female" is or should be. It was an advisor to President Teddy Roosevelt (1901-1909), sociologist Edward A. Ross (1866-1951), who actually coined the phrase "race suicide." 191 Around 1901, the teddy bear became a common chil-

188 Beatrix Hoffman, "Scientific Racism, Insurance and Opposition to the Welfare State: $\hat{E}$. Frederick L. Hoffman's Transatlantic Journey” in Journal of the Gilded Age and Progressive Era, 2 (2003), 150-190. The James Bryce to whom Flandrau refers may have been a British liberal, The Viscount Bryce of Bechmont, who in 1902, gave a series of lectures entitled "The Relations of the Advanced and Backward Races of Man" and was, in 1888, the author of "The American Commonwealth.” Bryce also became the British Ambassador to the United State in 1907.

189 Indianapolis Morning Star, February 8, 1907, 8.

190 Ibid. (Emphasis mine.)

191 Erich Goode and Nachman Ben-Yehuda, "Moral Panics: Culture, Politics and Social Construction”, in Annual Review of Sociology, 20 (1994), 149-171. 
dren's toy at the same time in both Germany and the United States. As cuddly as the bears seemed, it was not long before the teddy bear took on sinister connotations and came under attack in the name of "race suicide." Mothers had apparently been giving their daughters teddy bears to play with, rather than dolls. In addition to "a clergyman in one of the western states", the editor of "one of the most widely read women's fashion magazines" urged mothers to bring "your babies back to dollies or you will have weaned the grownups of the future from the babies that will never be." 192 The Boston Globe took a somewhat less serious view of the matter when its photographer found a group of girls holding "teddy bear dolls" and called upon the "pessimists to lay aside their gloomy forebodings." 193

Even the Roman Catholic Church became involved in question of the teddy bears. Rev. Michael Esper of St. Joseph's Catholic Church in St. Joseph, Michigan came to the attention of eastern newspapers when he asserted that teddy bears were "destroying all instincts of motherhood" in girls and would "in the future be realized as one of the most powerful factors in race suicide." ${ }^{194}$ Esper was reported verbatim as saying:

There is something natural in the care of a doll by a little girl. It is the first manifestation of the feeling of motherhood . In the development of the motherly instincts is the hope of all nations. It is a monstrous crime to do anything that will tend to destroy these instincts. That is why it is going to be a factor in race suicide problems if the custom is not suppressed. ${ }^{195}$

Esper's sermon earned him space in the Boston Daily Globe from which a reporter was sent to interview women at random on the issue. This Globe reporter interviewed many women but his search for supporters of Rev. Esper was reported as "fruitless." This "naturalization" of motherhood as a response to "race suicide" is common throughout the period in which sterilization laws were passed and these examples serve to support this idea. They could also be an example of factors at work in the Midwest "countryside", which included Indiana, that were taken less seriously in more "cosmopolitan" seacoast cities, showing an urban-countryside split. ${ }^{196}$

While science was perceived as beneficial, it could also create instability with the knowledge it generated. In the Star's "gossip column” for 18 January, the Editor noted that Dr. Hurty "is busy in the lobby...[talking] germs and microbes and cultures to legislators until they almost take to their beds." ${ }^{197}$ Hurty gave a speech about tuberculosis in late January to the House of Representatives. Using a cost-benefit rationale, he

192 Boston Daily Globe, 27 October 27, 1907, SM 4.

193 Ibid. (Emphasis mine.)

194 The Washington Post, July 8, 1907, 1.

195 Ibid.

196 Boston Daily Globe, July 14, 1907, 15.

197 Indianapolis Star, January 18, 1907, 6. We will become more acquainted with Dr. Hurty below since it was he who founded the Indiana Department of Public Health, below. 
estimated that the disease cost Indiana five million dollars a year, "more than flood, famine, war and earthquake." ${ }^{198}$ Hurty's theories on the spread of tuberculosis were reported as dependent on ventilation. He said that:

fully 30 per cent of you will go home from this Legislature suffering with coughs, colds and diseases of the respiratory organs - all due to the poor ventilation of the chambers in which you are doing your work. Two former legislators, with whom I was well acquainted, died of consumption after returning to their homes, and one of them maintained to the hour of his death that he contracted the disease in this very chamber." ${ }^{199}$

Hurty's speech was described as "frightening" to the Legislature, since many of them knew the two members to whom he referred. While science may have been thought to be beneficial, it could also create both panic as well as a sense of relief with the knowledge it generated.

Science as an institution was involved in many areas of socio-cultural life in Indiana in 1907. As I have mentioned above, this involvement can be studied using the intersubjective categories of race, ethnicity, gender, citizen status, criminal/noncriminal, ability and political philosophy ${ }^{200}$. I will take a moment here to discuss the macro-level discourse of race as viewed through the prism of science.

We would do well to first review the history of race at the turn of the century. In 1906, according to Tuskegee Institute statistics, three whites and sixty-two blacks were subjected to extra-judicial mob violence and lynched in the United States, although

198 "Frightens the Legislature. Dr. Hurty shows Them Pictures and Discourses on Death.” Indianapolis Star, January 30, 1907, 11.

199 Ibid. We do know that in 1917, a Senator William T. Green complained that a "poorly vented Senate chamber and the fact that his desk was near a door" brought on his illness. Green died the next day. Again, in 1929, Senator George W. Sims of Terre Haute complained about the physical conditions of the legislature. He said, “The ventilation's bad, the window blinds are a disgrace and the desks so dirty you can't work ten minutes without being a sight!” It was not until after World War II that major improvements in the ventilation system were made in the legislative building.

200 Anarchism came under particular suspicion. On the national level, President William McKinley (1843-1901) had been assassinated five years earlier on 14 September 1901 in Buffalo, New York by an anarchist. More confirmation of the presence of anarchy was found on January 7, 1907, when selfproclaimed anarchists Alexander Berkman and Emma Goldman were reported as both being arrested in New York. Berkman had just been released form a New York prison after serving 14 years for an assault on Henry C. Frick during the Homestead, Pennsylvania riots of 1892. (Indianapolis News, January 7, 1907, 11.) In 1907, Goldman has just started to speak to a crowd of around 600 people when the police arrived. She was charged with making an "incendiary speech", a felony, along with Bergman as an accessory.

On the local level, on 3 January 1907, an “alleged maniac” opened fire on Hanley's daughter and her husband as they left the house of Noah Garman, where they had been vacationing. Hanley's daughter, Ethel Hanley Garman, was married to Professor Harry O. Garman who was a member of the faculty at Purdue University in West Lafayette, Indiana. ("Maniac Shoots at Hanley's Daughter." Indiana Morning Star, 3 January 3, 1907, 1.) 
the NAACP considers these statistics “conservative.” Throughout 1907, lynchings were widely reported and, on 5 January 1907, the Indianapolis Star wrote of a black man who had "recently returned from the penitentiary" in Alabama. He had entered the room of the daughter of a "prominent banker at Midway", grasped her hand "before she awoke" and was scared away by her screams. After he was caught, "he made a full confession and the lynching followed." ${ }^{201}$ Lynching news was regular fare in this Indiana newspaper and the majority of the lynchings were of African Americans. However, five days later another lynching was reported, this time of a white man. In Charles City, Iowa, James Cullen allegedly murdered his wife and 15-year-old stepson. He was then "taken from the Floyd County Jail by a mob and hanged to the Cedar River Bridge, in the heart of the city."202 The lynch mob even included "four or five ministers and a large number of women..."203 Other intersubjective groups became involved in the violence as a method of belonging. As Cynthia Skove Nevel writes, joining in the lynching process was also a way in which immigrants, who were seen as neither white nor black, could prove their "whiteness" and establish their credentials as community members. ${ }^{204}$

Discourses concerning race and "race suicide" also articulated with the issue of marriage between races. Race suicide was allegedly practiced through miscegenation. In January 1907, South Carolina Senator Benjamin R. "Pitchfork” Tillman (1847-1918) attracted a large group to the Senate where he spoke on the "race question" in connection with the "Brownsville Affair." 205 The so-called Brownsville Affair took place on 13 August 1906 in Brownsville, Texas where a white bartender was killed and a white police officer was wounded during a disturbance. The disturbance was blamed on an all-Black U.S. Regiment that was camped in town. Roosevelt dishonorably discharged 167 members of the unit without trial or an opportunity to be heard. ${ }^{206}$ Theodore Roosevelt himself acted as prosecutor, aided by Joseph Foracker (1846-1917), in the indictment of the 167 enlisted men of the all-Black U.S. Twenty-fifth Regiment. On the 16th, the News editorialized about Tillman and the response to his speech. Beginning by noting that Tillman "never makes a speech that is not a direct incitement to race antagonism", we read that Tillman was also "trimmed" by Wisconsin Senator

201 "Mob Hangs Negro. Attempted to Assault Girl. Body is Swung to Tree at Midway, Ala. And Then Riddled With Bullets.”Indianapolis Star, January 5, 1907, 2.

202 "White Man Lynched. Sheriff Gives Way to Mob. Slayer of Wife and Stepson at Charles City, Ia. Is Hanged to Bridge.”Indianapolis Star, January 10, 1907, 1.

203 Ibid.

204 Cynthia Skove Nevel, Lynching to Belong: Claiming Whiteness Through Racial Violence (College Station: Texas A \& M University Press, 2007).

205 "Races Will Not Mix, says Tillman. South Carolina Man Fires some Hot Ones at Roosevelt and Foraker. Senate Galleries Packed. Headliner in the Upper House Takes Brownsville Affair as Basis for His Widely Advertise Speech.”Indianapolis News, January 12, 1907, 1. Lead Story, flush right column. 206 President Richard Nixon later pardoned all of the soldiers. 
John C. Spooner (1843-1919) who quoted Tillman as saying of the African-American population that "We shot 'em; we killed 'em, and we'll do it again."207

The category of "ethnicity" is porous and often intermixes with status as a citizen. On January 7th, the lead story in the Star concerned itself with the subject of Immigration. Frank Sargent, then the Commissioner of General Immigration in Washington, D.C., had submitted a report to Congress at the end of the fiscal year - June 30, 1906 giving the number of immigrants who had entered the country; the total number was $1,166,353 .^{208}$ According to Sargent's information and his interpretation of the situation, they were mostly from central and Eastern Europe, "inhabited by races nearly akin to our own" and they came to the United States because of the "general unrest existing among laboring classes." The headline used for this story is very interesting from a rhetorical standpoint. We can tease out more meaning from the headline if we change the noun "immigration" it to the noun, "immigrants." The immigrants are deemed a "flood", insinuating a threat or a danger of some sort. This only served to accentuate the word "army" in the phrase "army of 1,166,353." Not only is there some sort of threat or disaster implied but there is an additional threat because the quality of these persons is "below standard." We are not told what the standard of comparison is but one could easily think that it was the "bench-mark male" mentioned in Chapter 2. We are merely treated to conclusions in this article, i.e. "That the physical and mental qualities of the aliens we are now receiving is much below that of those who had come in former years, [Sargent] says, is evident."209

A third example of scientific discourse at the micro-level in Indiana is as it was applied to youthful criminals. Science became part of the newly established Juvenile Court system in Indiana, the first of its kind the United States, aside perhaps from Pennsylvania. In the Marion County Courthouse, two rooms previously used by the City Park Department were being vacated to allow the establishment of the first ever in the United States proper - Juvenile Court. One of the rooms was clearly a waiting room and the other was a "court room" in which "no effort has been spared to make them as cheerful and as little like courtrooms as possible." The desk for the presiding Judge - Judge Stubbs - was not on a raised platform and there was no bar separating the Court from participants. The "prevailing theory" of the Court was to give children the sense that they had "a friend in the court" making it easier for them to converse freely and truthfully so that a "heart-to-heart" could be had with the Judge.

A room was also appropriated by the Juvenile Court for use as a medical clinic, operated by Miss Eleanor Ketcham. She had been using jury rooms on the third

207 “Spooner and Tillman.”Indianapolis News, January 16, 1907, 6.

208 "Immigration Flood Breaks All Records. Army of 1,166,353 Aliens Admitted to the United States in One Year. Quality is Below standard. Steamships Blamed for Foreign Labor Importation.” Indianapolis Star, January 10, 1907, 1. I define "lead" story as the story in the upper left hand side of the newspaper. 209 Indianapolis Star, January 10, 1907, 1. 
floor of the Courthouse for her clinic and had to vacate the room, taking her "paraphernalia" into the hall when a jury began to deliberate. These medical examinations were "one of the most important branches of this work" since physical defects accounted for the "troubles" that initially brought the children before the Court "in a great many instances." Correction of these physical troubles "worked wonders on the children." ${ }^{210}$ In January, when Judge Harold Salamon, a representative of the government of Sweden, visited the one room Court, he had observed "What a wee bit of a courtroom. How do you manage to transact so much business here?... And the odor; it is not well ventilated." Judge Stubbs was reported as "barely kn[owing] how to answer [the question] intelligibly" at that time. ${ }^{211}$

This clinic was a vital part of the entire process and examinations were carried out as a matter of routine. Head of the physical exams was Dr. Walter Hoskins who determined, among other things, if a child was "mentally defective."212 When a boy entered the clinic the physical director of the Boys Club, Walter Gudel, first interviewed him about his family. The boy then went to Dr. Walter F. Kelly, who was in charge of physical measurements including weight, lung capacity (expanded and collapsed) and head measurements in different directions. Deafness and eyesight are also tested for. The child then went to Dr. Hoskins who was then a lecturer on children at the Indiana Medical College, affiliated with Purdue. The doctor dilated the boy's nostrils and the throat was inspected. Heart and respiration were also checked. If the doctor had any doubts about the health of the child, further examinations were done at other clinics. The examinations for girls were the same as for the boys.

Science was applied those defined as "criminals" even if juveniles. To underestimate the depth of this discourse would be to misunderstand how science was intertwined with daily social life. The legal concept of "insanity" in the sensationalized Thaw case is an example of this. The defendant, Henry Kendal Thaw, had allegedly murdered architect Stanford White who was the cosmopolitan descendant of two American presidents. As part of Thaw's defense, a new concept of legal insanity was used, as modified by modern psychiatry. As part of the Star's "gag photographs", a photograph of Stanford White in profile was printed and the skull area divided into five cells, each with an enclosed cartoon. The five compartments were entitled "incapability", "intemperance”, "destructiveness", "lack of will power” and "high living." In addition, "science" was again represented in the picture, albeit half-humorously;

210 "New Room is Ready for Juvenile Court. Quarters and Room is Vacated by City Park Department to Be Occupied this Week. First Trials On Wednesday. Equipment Does Away with 'Bar of Justice'.”Indianapolis Star, 10 February 10, 1907, 10.

211 "Juvenile Courts Ask for Larger Quarters. Petition to Be Presented to county Commissioners. Impressions of Visitors." Indianapolis News, January 1, 1907, 7.

212 "Systems of Clinic in Juvenile Court. Boys and Girls Examined by Specialist Each Tuesday and Thursday. Observations are Indexed. New Department Find Many Friends and Advocates." Indianapolis Star, August 12, 1906, 7. 
a solid bold black line was drawn around White's actual skull curvature showing a "normal head" while a dotted bold black line was drawn on the picture to show "the abnormal head." ${ }^{213}$ At this time a basic epistemic uncertainty of what was "sane" and "insane" existed within the legal system and this was true not only in the United States but would be true for Norway in 1934. Who and how the new jurisprudence would affect also depended on one's intersubjective group or groups.

\subsection{Linking "Race Suicide", Suffrage and Womanhood in Indiana}

One of the main discourses in Indiana newspapers in 1907 - if not the main one - was that the role of women in a society. In hindsight, we can see that Indiana was inexorably moving in some other direction than that of the pre-modern Pescosolido structure. The two main questions that emerged regarded the role of women in "race suicide" and their right to vote. As to the former, the discursive narrative questioned whether or not women were responsible for "race suicide", and if so, which women?

On the second day of January, 1907 the editor of the Indianapolis Star, in his daily column that was normally full of various comments and witticisms, was reduced to saying that the "safe and sane New Year was lost in the shuffle."214 On the front page that day, another story announced that there was "No Race Suicide in New York" given the fact that the "birth record [for 1906] is the greatest ever reported." 215 However, the state of Indiana was not to be outdone by New York and on 3 January, one day later, the birth statistics for Indianapolis were printed. ${ }^{216}$ In 1906 there had been a total of 2,118 males and 2,022 females born in the city. Of this number, the figures were then divided into "white" and "colored."

Despite the numerous discourses about race suicide, these articles concluded there was no such phenomenon. In retrospect, we can see that the total population of the Untied States had risen by 1.6 million, from 85,436,556 to 87,000,271, between 1906 and 1907. ${ }^{217}$ Progressive public health reforms also made an impact. As Michael Haines writes:

Reliable cause of death information for larger areas of the nation become available in 1900 with the initiation of the Death Registration Area (Preston, Keyfitz, and Schoen, 1972). Calculated from these data, the crude death rate declined by $38 \%$ between 1900 and 1940, while mortality

213 Indianapolis Morning Star, February 15, 1907, 2.

214 Indianapolis Star, January 2, 1907, 8.

215 Ibid., 1.

216 Indianapolis Star, January 3, 1907, 4.

217 Vital Statistics of the United States, 2000 (Hyattsville, Maryland: U.S. Department of Health and Human Services, Centers for Disease Control and Prevention National Center for Health Statistics, 2002), Table 4-1. 
from all infectious and parasitic diseases was reduced by $88 \%$. Infectious and parasitic diseases declined from $43 \%$ of all deaths to only $15 \%{ }^{218}$

This would tend to imply that people were either ignoring their own experience of life or that the Indianapolis Star, among others, was involved in a type of masterframed "propaganda."

But the rhetoric of "race suicide" was very powerful and it persisted in the media. It often pitted various institutionalized religions against one another ${ }^{219}$ For example, in 1908, the Post reported on an article by the Rev. G.L. Cady, a Congregationalist Minister from Dorchester, Massachusetts. Cady wrote an article declaring that the "Puritan stock is committing race suicide." ${ }^{220}$ Calling the demise of his Puritan church "involuntary harikari", he noted with chagrin that the "Catholic church has a great army of children coming up each year, native born, and the priest knows just what he can count upon for confirmation each year, and he knows that next year there will be just as large'a [sic] crop to harvest." ${ }^{221}$ Cady's use of military and agricultural metaphors is interesting and demonstrates just how powerful the idea of a threatened population can be.

Despite evidence to the contrary, the burden of "race suicide" was directly linked with the role of women in society. One of the most obvious signs of the structural shifts that were taking place was that women demanded universal suffrage. No longer were women confined within the concentric circles of a pre-modern Pescosolido model. Women were active in society at all levels from municipal to international and wanted recognition of that fact. For example, on the final day of January, the House Committee on Rights and Privileges, of which Committee on Medicine Health and Vital Statistics (CMHVS) ${ }^{222}$ members Keller, Porter and Izard were members, heard testimony from Mrs. Helen Gouger the "foremost exponent of women's rights in Indiana" and the head of the State Suffrage Association. ${ }^{223}$ This was not to be her only engage-

218 Michael Haines, “The Urban Mortality Transition in the United States, 1800-1940” in Annales de démographe historique, 1 (2001), 33-64.

219 This type of rhetoric can be found in more recent times in the speech given by then President S. Milosevic in 1989 where he made the large Albanian families in Kosovo into a threat against Serbia. Kosovar women were having more children than Serbian women. The phenomenon can also be seen from a religious nationalistic perspective in the rhetoric of the Croatian League of Families, in IsraeliPalestine debates and even in Norway within, most notably, the Fremskrittsparti (Frp).

220 The Washington Post, November 14, 1908, 6.

221 Ibid.

222 The CMHVS (Committee on Medicine Health and Vital Statistics) was the Indiana state legislature committee that reported the sterilization bill back to the legislature as a whole for passage. The CMHVS and its members are examined below.

223 "Women Should Vote. So Said Mrs. Helen Gougar. Noted Suffragist Addressed House Committee, but Found No One Who Would Volunteer to Champion Bills She Wants Presented.” Indianapolis Star, January 31, 1907, 4. 
ment at the General Assembly during the 1907 session. Approximately one week later, she addressed the entire Assembly in the House chamber and asked that a bill be passed giving women the right to vote in municipal elections. ${ }^{224}$ She was invited by Rep. J.M. Cravens who himself had introduced a similar resolution the day before in the House, which after being endorsed by Rep. Edwards, had been unanimously accepted. Her 30-minute speech had some effect since, after it was over, Rep. Beyer said he would "introduce her bill and fight for it."225

Gouger's talk on women's rights is classic but what is of more interest is that we see in it an example of the articulation of "the attachment or 'joining' of distinct discourses to one another." ${ }^{226}$ In her speech, Gouger said:

Let us vote, and I promise you that you will not have to build an additional cell in your State Prison in the next 100 years. We will reduce the population your insane asylums and we will empty your poor-houses. Besides all this, we will reduce your taxes. ${ }^{227}$

Exactly how this was to be accomplished is not mentioned but, again, this was only a 30-minute speech. In effect, Gouger implicitly set the blame for the chaos in the state's welfare systems at the feet of male legislators, in a "we can do it better" type of logic. We also read that men in the legislature who supported women were called "Miss Nancy's", clearly an attempt to impugn their masculinity. ${ }^{228}$ Gouger herself paid keen attention to the bills that were passed in the Assembly. When, for example, a bill was passed that added a period of disenfranchisement for criminals equal to the years the person was in prison, she wrote a letter to the Editor of the News in which she noted that it was an "insult to every woman citizen to be made the peer of criminals" and that women would rather "be in the legal companionship of law-abiding decent men."229

Two suffrage bills had been set in motion, but on 16 February they had both been set as an order of business for the very last day of the session, March 11. This was done, so the Star reported, while the House was in a "jocular" mood but several members said the action would be reversed in time for the bills to be voted on by the Senate. ${ }^{230}$ One week after her first speech, two hundred women attended Gougar's

224 This was a tactical move. If women could vote in municipal elections it would be more difficult to argue against their participation in state and national elections.

225 "Woman Addresses General Assembly. Mrs. Helen M. Gougar Pleads for Enfranchisement of he Sex in Local Elections. They Would Overcome Evils. Speaker Said Need for Prisons Would Be Decreased.” Indianapolis Star, February 7, 1907, 4.

226 William Sewell, Jr., The Logics of History: Social Theory and Social Transformation (Chicago: University of Chicago Press, 2005), 339.

227 Indianapolis Star, February 7, 1907, 4.

228 Ibid.

229 Indianapolis News, February 15, 1907, 4.

230 Indianapolis Morning Star, February 15, 1907, 2 and 23. One day earlier, in Chicago, the executive 
second talk and House members "gallantly" gave their seats to the women but most of them "remained away" for the talk. Miss Lydia Blaich, who was supervising Principal of Public School No. 15, opened the meeting by saying she had belief in the "greatness of the American man." Gougar then spoke, denouncing, "the high [liquor] license bill" pending in the House saying if women composed the House, the bill would be defeated. Giving women power would ensure that "the welfare of each shall be the concern of all.”

At the end of her speech, Gougar asked all those who supported suffrage to stand. Every woman stood but only two or three men joined them. At that point, Rep. Horace Hanna "strayed into the chamber" and sat down. As several women "glanced sharply at him" he held his ground "bravely and refused to stand."231 Gougar then asked all those opposed to suffrage to stand. Only one man, Rep. Baker of Elkhart County, had the "temerity" to stand. "Two hundred pairs of eyes looked at him pityingly at him, but he did not flinch." Gougar then asked how many were "on the fence" and no one stood. She retorted that these "are barbed wire times and no one wants to sit on the fence."232

Meanwhile, reactions to the demand for universal suffrage in Europe produced actual results. On 18 April 1907, the editor of the Star noted in his columns that the

little duchy of Finland, where, for the first time in the history of modern civilization, the political franchise and the right to legislate and other political office have been fully conferred on women, and where, moreover, these new rights have been energetically and promptly exercised the new Finnish diet will have among its members nineteen women elected by universal suffrage. ${ }^{233}$

Readers were aware, to a greater or lesser degree, that the universal suffrage issue would not disappear. Shifting structural changes were making the "highly nervous times" only more unstable, and the soon to be passed sterilization law would serve to underscore this. ${ }^{234}$

committee of the National American Women's Suffrage Association inaugurated a plan to enact a constitutional amendment that would give women the right to vote in national elections, without reference to any property qualifications. This committee was told that "liquor interests" in the Southwest were fighting against suffrage. Miss Laura Gregg of Guthrie, Oklahoma reported, "great corporations of the Southwest are energetically engaged in a propaganda against women suffrage.” Relegated to the home - private - sphere, women experienced the real life effects of alcoholism and tended to support anti-drink laws thereby incurring the anger of these "great corporations."

231 Indianapolis Star, February 19, 1907, 4.

232 Ibid.

233 Ibid., 8.

234 Two articles in adjacent columns on the front page of the Star give us an idea as to how the construct of real or natural "womanhood" was in 1907 was in the process of destabilization. In the middle of the page was a story about Mrs. Ruth Prindle, who gave refuge to a young Negro and protected him in her house for an hour against 200 angry glass workers who were "surging against the doors, hurl- 


\subsection{Structural Changes and Moral Panic in Norway (1934)}

In 1907, the similarities between Indiana and Norway were minimal. By 1934, social structures had begun to change, however. Norway had an extremely homogeneous society, with the exception of ethnic Sámi people and the Romani. Indiana, and the United States in general, was more populated and the movement from rural living to urban living was just beginning, as was industrialization. In 1907, economics in the United States were beginning to indicate just how large an industrial giant it would become in the $20^{\text {th }}$ century. On the other hand, Norway was a relatively poor country with millions of its citizens having departed for a better life, such as in Minnesota, a scant 30 years earlier. All of this changed in the intervening 30 years as, in the words of Jonathon Moses, Norway played economic "catch-up" to the point where, in 1934, it began to face the same challenges that Indiana had faced in 1907.235 Norway also played a form of "social" catch-up in addition to its economic "catch-up."

When the Norwegian Parliament, the Storting, passed its sterilization law in 1934 reform movements were also at work. ${ }^{236}$ The same conditions that had provided momentum for the Progressive Movement in the United States had developed in Norway. Along with Indiana in 1907, "business monopolies, dishonest politics, crowded city slums, and poor working conditions in factories and mines" in Norway, 1934 provided the impetus and rhetoric for an equivalent [progressive] movement there. ${ }^{237}$

In 1934, Norway was a very young country. In 1884, after having established a parliamentarian form of government, Norway faced a fight for independence from Sweden. A consular issue was the trigger that, in 1905, forced the issue of complete independence for Norway. After a parliamentary vote for independence in Norway, Swedes demanded an additional referendum and, with a vote of 368,392 to 184 ,

ing stones and curses." While women had done this before and some would, no doubt, continue to do this, this is a story of the threat of volatile lawlessness in society coupled with the fact that some women could be fearless. In the very next adjacent column, as if the typesetter were (unconsciously?) debating the role of women, was a story about one Miss Geraldine Smith who entered a bar in a "white silk dress, décolleté" with three "bewhiskered Turks in gaudy robes and a bevy of pretty girls, blondes and brunettes, who lined up at the bar and called for highballs, gin fizzes and the whole menu as they put dainty heels against the brass rod, smoked cigarettes, kicked high in the air and behaved most unseemly for ladies." Clearly this was some sort of public theater, but nonetheless mocked societal restrictions on women. Please see "Woman Saves Negro From an Angry Mob. Locks Him in Her Home While Enraged Factory Men Demand Vengeance. Black Stabs White Worker. Police Get Pursued Man and Arrest Mob Leaders.” Indianapolis Star, March 30, 1907, 1.

235 Jonathon Moses, Norwegian Catch-Up: Development and Globalization before World War II (Aldershot and Burlington: Ashgate, 2005).

236 David P. Thelen, Entry for "Progressive Movement” in The World Book Encyclopedia, 15 (Chicago, London, Sydney, Toronto: World Book, Inc., 1993), 817.

237 Ibid. 
Norway became independent in August 1905. The Norwegian Storting chose Prince Carl of Denmark to become King Håkon VII (1905-1957) of Norway.

Between about 1865 and 1914, the gross domestic product "more than doubled" growing from "28,431 to 79,519 million kroner (in constant 2000 prices)." 238 In 1910, $42 \%$ of the population was involved in agriculture and forestry. This was reduced by about 5\% ten years later, in 1920. The advances made in industrialization were cut short, however by World War I. The war largely reduced the number of ships in Norway's merchant marine, a war wherein Norway remained neutral. In 1920, Norway joined the League of Nations, the precursor to today's United Nations. ${ }^{239}$

Norway again declared itself a non-belligerent as World War II began in Europe. However, this did not prevent Norway putting the 1,000 ships in its merchant fleet at the disposal of the Allies. But, as most had feared, Nazis forces invaded Norway on the morning of 9 April 1940 in Operation Weserübung. Norwegians resisted the invasion but Speaker of the Norwegian Storting (Parliament), Carl Hambro, understood the gravity of the situation. The royal family, the Cabinet and 150 members of the Storting left Oslo on a train that same day. Eventually the King and Cabinet left the northern city of Tromsø on 7 June 1940 on a British vessel to set up a government in exile near Windsor Castle. ${ }^{240}$

Six years earlier, in 1934, the political atmosphere in Oslo was like a heated furnace. Approximately one year previous, on 17 May 1933, the Nasjonal Samling (NS) had been founded. Eventually, under the leadership of Vidkun Quisling this party entered into an accommodation with the Nazis, whose forces marched into Norway in June 1940. But six years earlier, in April 1934, members of many political groups in addition to the NS shared the same streets of Oslo - Communists sympathetic to Stalin's government, Workers Party members focused on the unemployment issue, rightwing Høire ${ }^{241}$ conservatives planning to take power in the coming October elections, and members of the Farmer's Party as well as followers of Quisling.

However, in the political cauldron of spring, 1934, some groups refused to share the streets of Oslo with each other, especially at night. On the night of 26 April, NS and Communist youth fought in the slushy streets of Oslo. The NS youth had gathered outside the Gjestetova Café in Tullinløkken and, when the Communist group arrived, fistfights broke out. As the fight progressed, rocks were thrown, and the plate-glass window of the restaurant was broken. Five persons were taken by the police, held for an hour and then released. The police announced that they were eager to investigate

238 Jonathon Moses, Norwegian Catch-Up, 48. Note 235.

239 Carl Joachim Hambro (1885-1940), was also the President of the League of Nations, when on 3 September 1939, World War II began.

240 On 7 June 1945, King Håkon VII and the royal family returned to Norway aboard a British vessel to face the damage done by occupation Nazis forces.

241 Today the spelling of Høire is usually Høyre. 
the whole affair and were sure that after a thorough investigation, at least a couple of people would be arrested. ${ }^{242}$

The year 1934 - the year in which the Norwegian parliament, the Storting, passed into law its sterilization law (1 June 1934 Lov om adgang til sterilisasjon ${ }^{243}$ ) - was only the $29^{\text {th }}$ year of the formal existence of the modern nation state of Norway. After the population had reached and exceeded the two million mark in 1890-1891, the population of Norway grew to approximately 2,266,200 million people in $1934 .{ }^{244}$ True, Norway's economy had improved since the nation's formal birth in 1905, but in 1934, both conservative and liberal media alike universally characterized the economic and political spheres in Norway as in a state of "crisis." Obviously, this crisis had not simply appeared on New Year's Day, 1934.

Hans Fredrik Dahl's description of the interwar period in Norway is extremely helpful as an overview of how this crisis had developed. Further, his descriptions are useful to us since he discusses the social life of Norwegians at this time. For example, in the 1920s and 1930s, he notes that even if cities had grown in size,

close to $1 / 5$ of all urban dwellers lived in apartments that statistically could be called "over-populated" in that between 2 and 3 persons lived in one room (where the kitchen then counted as a "room"). Most citizens lived in closely populated apartments (1-2 persons per room.) In 1930, in Oslo's eastern section, $1 / 3$ of the entire population lived in conditions where as many as 5 persons lived in one room and a kitchen; in the western section of Oslo the number of people who lived life this was close to $5-10 \%$ of the population. ${ }^{245}$

Unemployed men were either in over-crowded homes or walking the streets of Oslo, Bergen and Trondheim, Norway's three largest cities. Work was scarce. In the 1920s, life in Norway can be viewed through the lens of a lack of money but in the 1930s it can be seen as overshadowed by a lack of work, according to Dahl. Strikes and lockouts were common and led to an average annual loss of a million lost workdays, ten times higher than the average after the war, from $1945-1965 .{ }^{246}$ Farming as a way of

242 Aftenposten (P.M. Edition), April 27, 1934, 2. I use this example of the type of news one finds in the two major daily newspapers of Oslo in 1934, and even today. Norway is still a very small country, around 4.5 million, and this is reflected in the newspaper media. For example, the murder of a single taxi driver in Oslo is headline news while in Indiana today this would probably not be mentioned on the front page of the major newspaper. A positive feature of this smallness is that details are given which one does not find in US print media.

243 Unlike American legal citations, laws in Norway are cited to by the date of their enactment.

244 Chief source: Statistical Yearbook of Norway, Norwegian Central Bureau of Statistics, at http:// www.ssb.no/histstat/aarbook/1890.pdf, accessed 5 July 5, 2009. Also see, http://www.uu.nl/Bibliotheek/pages/default.aspx, accessed on 5 July 5, 2009.

245 Hans Fredrik Dahl, Norge Mellom Krigene/Det Norske Samfunnet Krise og Konflict 1918-1940 (Oslo: Pax Forlag A/S, 1971), 10.

246 Ibid., 15. 
life was beginning, ever so slightly, to decline. Marriages that in 1920 had produced 4 children per household were, in the interwar period, producing only 3 children per household. ${ }^{247}$

The economic situation of the working class was difficult during this time in Norway. Unemployment was a serious problem and one year before the United States established the CCC (Civilian Conservation Corps) in 1933, Norway had already established conservation camps for the unemployed. After the relative high employment, especially in the ship building industries during WWI, in the 1920s stock prices fell to half their value and timber sales were also cut in half. ${ }^{248}$ Unemployment among trade union workers rose from an already high 17.6 per cent in 1921 to 25.5 percent in 1927. ${ }^{249}$ The annual report of the Norwegian Electricians and Power Station Association (Norsk Elektriker og Kraftstasjonforbund) said in 1932 that:

The economic crisis is increasingly ill-natured and the unemployment is reaching...new all-time
heights. This is a picture of a society at war with itself and those who govern are not capable,
or willing, to point out how to get out of this mess.... We have an administration which by all
means seeks to load the burden upon the shoulders of the working man...[A government] that
conceives new laws to imprison and silence the labor movement and the working class, but is
unwilling to carry out measures to deal with the ever increasing numbers of unemployed.

Various social safety nets did exist and were at work. These included, for example, the Poor Relief System ${ }^{251}$ and the Norwegian Vagrant Mission ${ }^{252}$ but with one of every four workingmen out of work, the concept of "enough" was not open to much interpretive quibbling among that class of citizens.

Nonetheless, in some quarters there were monetary resources. For example, the Høire ("H") Party had announced on 9 February 1934 that the Høires Hus, a new, seven story, modern building would be built under the Chairmanship of attorney Henrik Bergh (1879-1952). ${ }^{253}$ With $822 \mathrm{~m}^{2}$ of available space, there would be more than enough space for the Høire Party to operate, and have its offices and clubs. The ground breaking would be sometime in October, 1934. ${ }^{254}$

247 Ibid., 11.

248 Magnus Jensen, Fra 1905 til våre dager, (Oslo: Universitetsforlaget, 1968), 44-45.

249 Ibid., 47.

250 Found at http://www.heis.no/search details.aspx?docid=85, accessed December 9, 2007. (Emphasis mine.)

251 "Fattigvesent." Aftenposten (A.M. Edition), January 15, 1934, 2.

252 "Den norske omstreifermisjon." Aftenposten (A.M. Edition), April 20, 1934, 3. We will encounter this group when we discuss the various "identities" being formed in society, i.e. "others" such as "taterne" ("the travelers"), homosexuals and other ethnic groups such as the nomadic Samí.

253 Bergh would later defend V. Quisling in his trial for treason.

254 Aftenposten (A.M. Edition), February 9, 1934, 2. 
Politically, the most important parties in Norway in 1934 were the Conservative Party (Høyre ${ }^{255}$ ), the Liberal Party ${ }^{256}$ ("V") and the Labour Party (Arbeiderpartiet, "Ap"). Other parties were present and these included the Farmers Party (Bondepartiet, "BP") ${ }^{257}$ founded in 1920, the Society Party (Samfundspartiet, "Sp") founded in the early 1930s, Quisling's Nationalist Party (Nasjonal Samling, "NS") ${ }^{258}$ founded in 1933 as well as the secular liberals (Frisindede Venstre, "FV") founded in 1932. ${ }^{259}$ At this time, it was virtually impossible to form a stable coalition government, according to Dahl, and during this period, Norway had 10 governments within 15 years with the "average [survival period] of the governments similar to France's Third Republic."260

Understandably, Norwegian society was experiencing a sense of angst about the future of the country just as Indianans had experienced their own "moral panic" in 1907 over "race suicide." Whether or not the word "angst" is a technical sociological term that is usually applied to certain historical times, the above data supports the use of the word in relation to this period. As Dahl notes, the processes of industrialization and urbanization plus inadequate and ineffective political institutions, when combined with more forms of communication ${ }^{261}$ made for turbulent times. But the most salient point that Dahl makes is that:

Social life was not calm. And that which was most of all not calm or in equilibrium was the citizens' understanding of each other: as friends, enemies, members of the same class, fellow countryman, patriots, traitors. These things were changed, essentially. The history of the interwar period is about them. ${ }^{262}$

Dahl's evaluation can be interpreted to mean that the sociology of the interwar period in Norge was also about these social relationships, relationships between individuals, groups and institutions and the amount of trust each had in the other.

Nevertheless, despite the political unrest, in strictly political terms, Norway was not as left-leaning as other Scandinavian countries. Between 1914 and 1930 the combined percentage of votes from Social Democrats, Communists and the Arbeiderpar-

255 This is today's spelling of the older word "Høire."

256 To American ears, this party might sound left of center. In Norway, it is consider right of center.

257 The Bondepartiet changed names in 1959 to become today's Center Party “CP”, (Senterpartiet, "SP").

258 The NS was founded on May 13, 1933 by Vidkun Quisling and existed until 1945.

259 The FV party only existed until 1936. "Frisindede Venstre" literally means "open-minded liberals" and was an offshoot of the Liberal Party, itself a "low church" party. While it might be more comfortable for English-speakers to have the acronyms changed from Norwegian to English, i.e. have the Arbeiderpartiet “Ap" changed to "LP” for "Labour Party", I have kept the party acronyms from the Norwegian words.

260 Dahl, Norge Mellom Krig, 16.

261 Ibid., 20. The radio had been introduced into Norwegian society in 1925.

262 Ibid. 
tiet membership in Denmark rose from $29.4 \%$ to $42.2 \%$, a $12.7 \%$ increase; in the same era, the percentage in Norway increased only half as much, from $26.3 \%$ to $33.1 \%$, or, a $6.8 \%$ increase. Sweden experienced a 12.4\% increase, Finland and Germany a 5.5\% increase while England saw a 31.2\% increase and France a 13.6\% increase. ${ }^{263}$ Although the Arbeiderpartiet had broken with the Soviet Komintern in November 1923, the fear of revolution "was not dead" in large part due to the labor problems in pre-WWII Norway. ${ }^{264}$

\subsection{Societal Changes and Moral Panic in Norway}

We will rise up to fight against this hedonism. We will rise up under the banner of St. Olav the Holy and proclaim that life is holy and inviolate.

Fru Eller Anker 265

Various types of "progressive” movements existed in Norway in 1934. The movement composition and institutional design were somewhat different but many of the goals were the same; these goals included addressing the situation of the poor in Norway including the homeless, mothers and children, the sick and the unemployed. By necessity, it also addressed the issue of criminality. As in Indiana, the progressive movement in Norway was, in the main, in the hands of middle and upper class women. Within that group, approaches differed by political conviction, with rightwing women more likely to join the Norges Husmorforbundet (NH) and idolizing its leader, Fru Marie Michelet. ${ }^{266}$ Left-wing, especially Arbeiderpartiet, women were more likely to stand in solidarity with Katti Anker Møller (1865-1945), Norway’s equivalent of America's birth control pioneer Margaret Sanger. ${ }^{267}$

As we saw above, the eugenics movement was also alive and well in Norway. The ideas of the eugenics movement were in print in daily newspapers just as in Indiana. Those who espoused eugenics as a science were also particularly busy and we will encounter Dr. Alf Mjøen and his Committee on Race Hygiene below. This group took

263 Ibid., 60.

264 Ibid., 65.

265 Aftenposten, (a.m. Edition), October 30, 1934, 3.

266 In 1915, Michelet was the first leader of the HVF's precursor, Hjemmenes Vels Landsforbund. She steered both organizations stressing a combination of conservative religious values and "rational", scientific housekeeping. In the 1970s, among other issues, the organization addressed the fact that women who worked in the home should receive "points" for their work there within the national social security systems.

267 Please see, Ida Blom, Barnebegrensing - synd eller sunn fornuft (Bergen: Universitetsforlaget, 1980), which is the seminal academic work on birth control in Norway. 
as one of its main goals, to influence national legislation and, when we look at the Storting debate, we will see how influential this lobby group actually was.

One narrative that both the eugenics and progressive movements rested on concepts of what it meant to be "healthy" and "unhealthy." One narrative of this idea can be seen in the 1934 Oslo visit of an exhibit that had originated in Dresden. Not only is it part of a narrative but it is also an example of the Jasanoff idea of a "representation", in this case a representation about the power of science as it related to motherhood and nationhood. "Healthy Mothers - Healthy People" was the subject of an article on 10 March in Oslo's afternoon edition of the Aftenposten. ${ }^{268}$ The article announced an exhibition that would be held in Oslo the coming autumn. ${ }^{269}$ It also mentioned that in 1927, another exhibit entitled "Humanity" had been held in Oslo and that no fewer than 83,000 persons had visited the exhibit. ${ }^{270}$ The autumn event was to be sponsored by the Hjemmes velstandsforbund ${ }^{271}$ (HVF) and the Norges Røde Kors landsforening (NRLF). ${ }^{272}$ The newspaper author was clearly excited about the event, mentioning that where it had been shown in other countries, it had a great number of attendees. The exhibit was described as easily intelligible and had many illustrations. It would give clear information on what would be needed in order to have a healthy child, family and lineage. ${ }^{273}$ While not named specifically as a "race hygiene" exhibition, it would not be unreasonable to assume that this material was included in the exhibit.

On 20 October 1934, the Crown Prince, HRH Harold, did indeed open "Healthy Mothers - Healthy People” at Håndverkeren. ${ }^{274}$ Along with the Prince was the President of the Red Cross, Lieutenant Meinich, Fru Michelet, the venerable President of the Norwegian Housewives Association (NHF), Prof. Arne Sunde, who we will meet when he debates with S.R. Bonde in a committee meeting pertaining to the sterilization law, Superintendent Bergliot Larsson ${ }^{275}$, the medical director for Oslo schools Dr. Lauritz Stoltenberg, and the Mayor of the Asker municipality, Lector Schiøtz.

268 "Sunde mødre - sundt folk." Aftenposten, (p. m. Edition), March 10, 1934, 7. Much ink has been spilled over the translation of the word "folk" in German. There is no exact translation from the German to English especially at this time in history. It would be speculative to render a connotative meaning for the Norwegian "folk" during this time. However, the word is used as a leit motif of health and motherhood.

269 A picture of the German poster for this exhibit can be seen in Sara J. Bloomfield, Deadly Medicine: Creating the Master Race (Washington, D.C.: United States Holocaust Memorial Museum, 2004), 24.

270 Aftenposten (p.m. Edition), March 10, 1934, 7.

271 For the Good of the Home Association.

272 "Hjemmenes Velstlandsforbund og Norges Røde Kors landsforening." Aftenposten (p.m. Edition), March 10, 1934, 7.

273 Ibid.

274 Aftenposten (p.m. Edition), September 20, 1934, 7. The title "Sunde mødre - sunt folk" could also be translated "Healthy mothers - healthy citizens."

275 Ibid. "forstanderinne" 
Both the 1927 "Humanity" exhibit and the 1934 "Healthy Mothers - Healthy People" exhibit were on loan and delivered from the Hygiene Museum in Dresden, which Meinich said, "has now for 25 years been at the center of hygiene information in Europe and which our land also stands in gratitude for." ${ }^{276}$ We could suppose that if Fru Michelet broke away from her duties at the NHMF national convention, also happening at the same time, numerous other members of the influential NHMF also visited the exhibition. One week after the hygiene exhibit "Healthy Mothers - Healthy People”, Norway's national Medical Director N. Heitmann bemoaned the fact that only 10,000 Norwegians had visited the exhibit and that this was "entirely too few." He urged everyone who could, to attend the exhibit since there was much to learn there for all ages and sexes. ${ }^{277}$

The work of the liberal wing of the progressive movements in Norway focused on providing birth control and securing less restrictive abortion laws, something that was not openly considered in the media in Indiana in 1907. The birth control debate itself had been highlighted in Norwegian society at least since Katti Anker Møller had made the concern of "worn out mothers" her life's work in the first decade of the twentieth century. ${ }^{278}$ In 1934 , however, the issue that was used to address the role of women was the abortion issue.

The birth control question was less significant in 1934 in Norway than in 1907 in Indiana, although advocates in Norway knew that the idea of women's access to it would continue to be attacked. ${ }^{279}$ America's birth control pioneer, Margaret Sanger,

276 Ibid. One of the exhibits, a glass, see-through replica of the human body is pictured in Bloomfield, Deadly Medicine, above footnote 1199.

277 Aftenposten (a.m. Edition), 27 September 27, 1934, 6.

278 Øyvind Giæver, “Abortion and Eugenics: The role of eugenic arguments in Norwegian abortion debates and legislation, 1920-1978” in Scandinavian Journal of History, 30 (2005), 23. Giæver makes the important point that there is a "danger of over-emphasizing" the role of eugenics in light of other "progressive causes" so as to make this period "more palatable" to the modern reader, (p. 39). Other forces were at work and earlier, on 18 October 18, 1913, Katti Anker Møller's letter entitled "Om fosterfordrivelse" (Concerning fetal abortion) was printed in the Social-Demokraten, the daily newspaper read by members of the labor movement. Nine years earlier, she had attended a Women's Conference in Berlin in 1904 where she had met other feminist and progressive personalities such as Susan B. Anthony, Maria Stritt, Lady Aberdeen, Mrs. Sewell, and Perkins and Gilman. (Tove Mohr, Katti Anker Møller - en banebryter (Oslo: Tiden Norsk Forlag, 1968), 69.

279 That there should be communication between birth control advocates on one continent and researchers on another continent in 1934 should not be a surprise. David Mitchell and Sharon Snyder have coined the term the "eugenic Atlantic" in relation to the building of an international science of eugenics. (David Mitchell and Sharon Snyder, "The Eugenic Atlantic: race, disability and the making of an international Eugenic Science, 1800-1945" in Disability and Society, 18 (2003), 843-64.)

They build on work done by Paul Gilroy on how social constructions cross between and among cultures. Gilroy focused on "trans-Atlantic traffic" concerning race and disability, coining the phrase "Black Atlantic" to mean "beliefs about racial and biological inferiority [that] dovetailed for a period of approximately 150 years in the cultural space...the 'Black Atlantic'.” (Ibid., 844. Please also see, 
had written to Dr. Otto Mohr (1886-1967) asking him to differentiate the Norwegian Mødre hygienekontorer ${ }^{280}$ from the German Sexüalbera Frugestellen. Mohr responded to Sanger on 2 August $1928 .^{281}$ He wrote that, in contrast to the Norwegian Mothers' Hygiene Offices, the German offices gave advice on "practically any sex questions." The Norwegian offices were primarily concerned with mothers; the head nurse gave answers to questions and contraceptives were sold within the office itself. Mohr compared these offices with the "English ones" in that the Norwegian offices sold literature on birth control, the care of children "and also practical outfit[s] for babies and for pregnant mothers." Although only two such offices existed at the time, as was the case almost exactly one year earlier, Mohr expected "more are going to be [erected] soon.” He credited his mother-in-law, Katti Anker Møller “the pioneer in woman's rights in our country" for the existence of these offices but says that they had "now been taken over and run by the Labour Party."282

Sanger asked Mohr for suggestions for Norwegians who might be interested in attending a birth control conference to be held in Paris in March the following year. Mohr answered guardedly, saying "I really must be very careful, that it is not easy to find any[one]" willing to attend. He suggested that Katti Anker Møller was the best person to talk to because she "knows from her long experience what to do and how to do it when it comes to the question of practical work.” Mohr saw Møller as commit-

P. Gilroy, The Black Atlantic: modernity and double consciousness (Cambridge: Harvard University Press, 1995). Mitchell and Snyder argue that whatever "socially stigmatized identity" one considers, the "eugenic Atlantic" categorized that particular "insufficiency" as if it were "biologically coded." (Ibid., 860.) And, whatever the nation-states' individual responses were to this, similar cross-national characteristics are found, especially legal cross-national characteristics. (Michael Mintrom, "Policy Entrepreneurs and the Diffusion of Innovation” in American Journal of Political Science, 41 (1997), 742.) Research has also been done on how individuals impact this policy formation, so-called "policy entrepreneurs." They play an "important role in articulating innovative ideas onto government agendas." (Michael Mintrom, "Policy Entrepreneurs and the Diffusion of Innovation" in American Journal of Political Science, 41 (1997), 742.) In terms of social movement theory, Doug McAdam has written about how both "diffusion" and "brokerage" in social movement theory as "different pathways to scale-shift." (Michael Mintrom, "Policy Entrepreneurs and the Diffusion of Innovation" in American Journal of Political Science, 41 (1997), 742.) In typical "cycles of protest" research, diffusion tends to be seen as creating "waves" or "cycles" and "the spread of actions" takes precedence over the work of individual agents. (Pamela E. Oliver and Daniel J. Myers, "Networks, Diffusion, and Cycles of Collective Action" in Mario Diani and Doug McAdam, Social Movements and Networks: Relational Approaches to Collective Action (Oxford: Oxford University Press, 2003), 175.) Here, I focus momentarily on one individual, Maragret Sanger, and the "network effect" she participated in with Norwegian feminists. I discuss the network she had with Norwegian actors and what function it had - if any - since the birth control movement in Norway was already fairly well established by 1934 .

280 Mothers' Hygiene Offices/Clinics.

281 Library of Congress (Washington, D.C., U.S.A.), Papers of Margaret Sanger, Accession Number 16,700, Vol. 29, Reel 19. Letter dated Oslo, 8/2 1928 (Mohr to Sanger).

282 Ibid., End, 1. 
ted to "the empowerment of women, in the broadest sense" and himself "of the same opinion." ${ }^{283}$ But with regard to Norway, Mohr said:

judging from your letter, you want members of [a] more scientific type, 'straight thinking economists and sociologists'. I am afraid we don't have any such at present who are really interested in practical birth control. The movement itself has during the latter years had a rapid progress in our country, but few prominent people have so far openly joined..$^{284}$

This is as good a description as one can find from that time period that describes the birth control social movement and its activities and strength in the country.

In 1934, relaxation of the abortion law also very seriously debated in the Norwegian public sphere, even more than the sterilization law was debated; sterilization after an abortion was also seen as a possible solution for poorer women. Indeed, the debate over sterilization of women within the context of a simultaneous abortion was advocated the very same month as the sterilization law itself was passed. Supervising doctors Dr. Kristen Andersen, Schilling and Dr. Widerøe, Dr. med. Skaja, Judge C.E.C. Bonnevie, Judge Hartmann and attornies J.M. Lund and Nørregård had submitted a proposed bill to the Odelsting ${ }^{285}$, a separate unit within the Storting, making sterilization an option at the same time as an abortion in cases where "it is reasonable to assume that the woman should not have more children." ${ }^{286}$ Here we have an

283 Library of Congress (Washington, D.C., U.S.A.), Papers of Margaret Sanger, Accession Number 16,700, Vol. 29, Reel 19. Letter dated Oslo, 8/2 1928. End, 2.

284 Otto Mohr was a scientist above all else. On May $4^{\text {th }}$, the Aftenposten reported on a speech that he gave to the Norwegian Scientific Academy on the subject of what he called "intersexuality." Mohr's lecture that day was on the potentiality of the fertilized egg, which he said, "...contained the possibility to develop into both the male and female sex.” (Aftenposten (p.m. Edition), May 4, 1934, 3.) He acknowledged that the situation was complex and that further research was needed on sex differentiation of the fetus including the control mechanisms, extra-cellular material, and the impact of male and female sex hormones. (Ibid.) American Leslie Clarence Dunn (b. 1893), visited Mohr at the University of Oslo in 1927 and he called Mohr an "outstanding investigator" in letters Dunn wrote back to his colleague, Walter Landauer, at the Storrs Agricultural Experimental Station in Connecticut. (Jenny Marie, The Situation in Genetics: Dunn's 1927 Russian Tour, Mendel Newsletter, n.s. 12 February 2004. Online at http://www.amphilsoc.org/library/mendel/2003.htm\#cain, last accessed December 10, 2007. Dunn was one of the founding members of the Genetics Society of America and its President in 1932. He replaced T.H. Morgan at Columbia after Morgan went to the California Institute of Technology in 1929.

285 After the Storting (Parliament) is gathered in October, and after the President of the Storting is elected, it divides itself into two units, the Odelsting and the Lagting. Please see, http://www.tinget. no/no/Hovedmeny/Hvordan-jobber-stortinget/Storing-Odelsting-Lagting, accessed September 18, 2009.

286 Doktor Ingeborg Aas, Kvinnen og barnet $i$ fohold til spørsemalet Abortus provacatus (Oslo: $\mathrm{H}$. Aschehoug \& Co. (W. Nygaard), 1935), 45. "Each of these proposals entertains the through that sterilization should be carried out at the same time as an abortion where it is reasonable to assume that the women should not have any more children." Bonnevie was a described as a sorenskriver, which 
example of "practical" reason, which is attempting to inject itself into the legislative process to become a legal norm.

That same month in the Storting, a Penal Code Committee was appointed and in August it also decided to take up the abortion issue. ${ }^{287}$ The Committee was composed of permanent members, as well as lawyers assisted by three medical doctors, Ingeborg Aas, Tove Mohr (daughter of Katti Anker Møller) and Kristjar Skajaa. Due to "immediate" criticism of the committee as being "radically" biased, the Ministry added 3 more members in October, Stian Erichsen, lawyer Aage Schou and surgeon Dr. Kristen Andersen, who had already brought up the idea of sterilization in connection with abortion procedures in 1929. ${ }^{288}$

This issue was also discussed at the annual meeting of Norwegian jurists in Oslo two months later, just as it had been the subject of Kristen Andersen's introductory remarks to the Norwegian Surgical Association's Annual Meeting seven years earlier, on 2 November 1929. ${ }^{289}$ Discussion about abortion was not new to Norway but what should be noted here is how both the legal and medical institutions had become intimately involved in the debate and that the legitimacy of various narratives hung in the balance.

While the Jasanoff "identity" field in relation to women was in epistemic chaos in Norway in the first few months of 1934, other body-law "identities" were forming. The two health problems that were consistently associated with regard to which bodies should be sterilized were mental illness and mental retardation - now called developmental disability. Another body-law identity was also in the process of being formed and this was within certain criminal populations. True, all these groups had women as part of their populations, although the criminal population was primarily male. But it is within the context of the unavailability of birth control to women who "should" not be having so many children, i.e. poor and uneducated women, rural women, and/ or religious women who would not use it, where the two discourses intersect. Discussions about changing the medical indications that would make it easier to have an abortion were numerous and it is here that the role of "women as mothers" attaches to the practice of sterilization. What is fascinating is that at this time, the same groups that defended the role of "women as mothers" also defended the sterilization of these "others", i.e. the bodies of the mentally ill and retarded. Just under the surface, this issue was actually framed to mean that "women as mothers" was "the right kind

is defined as a "judge (chief magistrate of a rural district; office of such a magistrate." Einar Haugen, Norwegian English Dictionary (Oslo Madison: Universitetsforlag University of Wisconsin Press), 386.

287 Øyvind Giæver, “Abortion and Eugenics”, 26. Note 483.

288 Ibid.

289 Kristen Andersen, “Abortus provacatus med særlig henblikk på dens mulige sociale og humanitære indikasjoner” in Tiddsskrift for Den norske Lægeforening, 49 (1929), 1191 -1215. On page 1212, Andersen introduces the idea of sterilization in connection with abortion. 
of woman as mother" - not coincidentally, the same narrative found in Indiana a quarter of century earlier.

That abortion and birth control were openly debated in Norway in the late 1920s and into the 1930s did not mean that all members of the progressive movement were united over these two issues. Late in October 1934, a protest turned violent at the Calmeyergatens Mission House where a large meeting heard attacks on the "Journal for Sexual Information” and parish vicar Joh. E/M. Wisløff proclaimed a popular uprising against changes to the Criminal Law $\S 245$ concerning abortion. This was a "call to arms" motivational meeting, a "core task" for framing the anti-abortion movement. The lecture hall was "filled from floor to roof" and after singing two verses of "A mighty fortress is our God", Wisløff denounced abortion as a "stake in the heart" and urged a popular uprising "from Lindesnes to the North Cape." ${ }^{290}$ Next to speak was res. Kap. Jon Mannsaaker on the theme "Life is holy"; the most important issue was the "religious and moral side of the case." Advokat Ingolf Sundfør (b. 1893) ${ }^{291}$ spoke next on the ramifications of legalized abortion on women and "humble folk", saying that they would both be damaged by the changes. ${ }^{292}$ Abortion would make women uncivilized and it would be a triumph for the lazy. Sundfør went on to say that the proposed changes would characterize a fetus as some sort of "womanly abscess." Carrying the theme of "abscess" forward, Sundfør said, "One could also say that the legal proposals can also be understood as types of human abscesses which, in the best case, have undergone the surgeon's knife." At the end of his speech, Sundfør proclaimed, "Down with cold-blooded murder! Life must live!"

Priests and attorneys were not the only speakers at the rally; women spoke as well. Dr. Kristine Munch spoke about the status of fathers under the proposal and

290 Aftenposten, (a.m. Edition), October 30, 1934, 3. The protest was held on 29 October and reported on 30 October 1934.

291 Sundfør was an attorney admitted to practice before the Supreme Court of Norway. He took it upon himself in the Aftenposten on 25 August 1934 to remind Oslo readers that there was a split of opinion between those living in the cities and those in the countryside. Sundfør argues that any changes in the law must be based on a moral experience and sets out 13 points. Sundfør's fourth point of the 13 is that marriage is the most important institution and in the fifth point asks if the father is a participant in the abortion issue and whether or not he has rights. His points become points aimed at the medical profession and he asks if a doctor really has the right to evaluate the social and humanitarian indications for abortion. His twelfth point maintains that it is incomprehensible that we recognize the principle that a beginning life can be sacrificed in order that the parents' life can be economically bettered, or more comfortable or so that they can have more possessions. To permit the murder of a beginning life in order to protect a later life that is ruined is like brushing away a mosquito while swallowing a camel. His thirteenth point is interesting from a semiotic standpont. He complains that the phrase "abortus provocatus" has such a civil ring to it. "It sounds like the name of a flower or a medicine." The law originally called abortion "fetus murder" and the new (latin) phrase hides the "mission" or "deed" itself.

292 Ibid. 
Bispinne $^{293}$ Petra Fleischer spoke about "sexual literature, which has engulfed the entire country" and the influence it was having on children. Lars Eskelund, a public high school superintendent, spoke on the fall of Greece and Rome because of "depraved" lifestyles. Ella Anker berated Tove Mohr as well as Dr. Kristen Andersen for their "backsliding." 294 Anker told the assembled, "We will rise up to fight against this hedonism. We will rise up under the banner of St. Olav the Holy to proclaim life is holy and inviolate." ${ }^{295}$ Parish vicar Ludvig Schübeier ended saying that these were the facts that should speak - and convince - the Norwegian people. ${ }^{296}$

Mohr and Andersen were not the only women to be berated as the next day Aimée Sommerfelt wrote for the Aftenpostens kronikk297, the purpose of which was to review a new book by dr. Olga Knopf entitled the "The Art of Being a Woman."298 In this book review, Sommerfelt attacked dr. Lisa Jacobsen and Margrethe Bonnevie saying:

we still have a recent memory of two direct opposites [of this type of woman] like dr. Lisa Jacobsen and fru Margrethe Bonnevie whose contributions we see in the daily press. ${ }^{299}$

Jacobsen and Bonnevie were important role models from an elite class of women who acted as "entrepreneurs" in the on going "role of women" debate. Mohr and Andersen were at least perceived by some Norwegian women - including Sommerfelt and Anker - as antithetical to the "real" role and identity of a woman in Norwegian society.

New Year's Day 1934 fell on a Monday and was a non-working day in the towns and villages of Norway. The first working day of the year, however, Norwegian newspapers began by noting that, in Germany, New Years Day 1934 was more than a traditional holiday. On that day, the "Law for the Prevention of Genetically Diseased Offspring” became operational, after becoming law on 14 July of the preceding year. Helping to draft this legislation were such luminaries of the German scientific world as Alfred Ploetz (1860-1940) and Ernst Rüdin (1874-1952), Director of the prestigious Kaiser Wilhelm Institute for Genealogy in Munich.

This was not news to Norwegian doctors. As a general rule, Norwegian doctors traveled to and from Germany at this time and would have known of this legal development. In fact, many doctors who were around 60 years of age in 1934 had visited Germany; as part of the traditional European "study tour”, Norwegian physicians

293 The title "Bispinne" refers to the wife of a Bishop.

294 Aftenposten, (a.m. Edition), October 30, 1934, 3.

295 Ibid.

296 Ibid.

297 A “kronikk" refers to what we now call an "op-ed" piece in a newspaper.

298 Aftenposten, (a.m. Edition), October 31, 1934, 2.

299 Olga Knopf, The Art of Being a Woman (New York: Blue Ribbon, 1932). Knopf, a psychologist, is probably now known only for her quote "The art of being a woman can never consist of being a bad imitation of a man." 
born between 1870 and 1875 preferred to go to Germany. The contrast between this group and those doctors born between 1840 and 1845, who also included France and Austria as a destination, is "striking." 300 Taking information from biographies in Norwegian Doctors (Norges Læger) and the Norsk Magazin for Lægevidenskaben (Norwegian Magazine for Medical Science), Bent Olav Olsen has calculated the most frequently visited of six countries, with one or more destinations in the study tour, as a percentage of all journeys and found that for those doctors born between 1870 and 1875, the percentage visiting Germany was $42.2 \%$. The percentage for Denmark was $25.2 \%$, for Sweden $11.7 \%$, for France and Austria each $9.1 \%$ and for Great Britain $6.7 \% .^{301}$ Although this need not necessarily mean anything sinister, it does speak to the idea that these doctors, who spoke and read German, would also likely have known of this development before it was reported in the press.

Paul Weindling writes that one of the architects of Germany's new law, Alfred Ploetz, "venerated Scandinavia as the motherland of the German [people]." ${ }^{302}$ Weindling also notes that the Scandinavians responded to racial hygiene "with great enthusiasm" which served to "reinforce...the ideal of Nordic racial purity" within Germany itself. Another architect of the new German law, Ernst Rüdin, visited Norway and Sweden in March of 1907 where he "recruited seven members" for the International Society for Racial Hygiene (ISRH); Rüdin returned again two years later on 7 May 1909 and recruited another twenty-seven members. ${ }^{303}$

The ISRH had institutional and individual contacts within Norway from its beginnings. It was a "constituent member" of the International Eugenics Committee (IEC) and, for example, on 3 August 1913 Ploetz met with George Darwin and Norwegian Dr. Alf Mjøen in Paris for a meeting of that group. ${ }^{304}$ There, Ploetz worked to have an IEC Congress held in Germany but the idea was defeated. Weindling writes that, after that idea was defeated, Ploetz' diary shows that he "consoled himself by drinking brotherhood with Mjøen who was an ardent Nordicist." ${ }^{305}$ We have met Dr. A. Mjøen above and will review more fully his contributions to the eugenics movement in Norway below. Suffice it to say, that the eugenics movement had a history dating back to the late 1800 s and had been in existence with several highly visible professional supporters.

300 Bent Olav Olsen, "Recreation or Professional Necessity? - The Study Tours of Nineteenth Century Norwegian Doctors" in Øivind Larsen and Bent Olav Olsen (eds.) The Shaping of a Profession: Physicians in Norway, Past and Present (Canton, Massachusetts: Science History Publications, 1996), 264. 301 Ibid.

302 Paul Weindling, Health, Race and German Politics Between National Unification and Nazism, 1870 - 1945 (Cambridge: Cambridge University Press, 1989), 150.

303 Ibid.

304 Ibid., 153.

305 Ibid., 151. Weindling continues throughout his book to call Mjøen a "racist." 
Eugenic ideas had taken root within various institutions, including welfare and religious institutions. Because there were no "waves" of "impure" foreign immigrant bodies to Norway, the only recourse was to examine the indigenous ethnic bodies. Religious structures as well as governmental structures intersected to consider these groups as objects for sterilization. While not a significant percentage of the population, Norway did have a variety of national minority groups, including "Samís, kvener, skogfinner, Jews, gypsies and not least of all, Romani-folk (taterne or 'the travelers')" ${ }^{306}$ Dr. Ingeborg Aas and Supervising Doctor Johan Scharffenberg had already raised the question of sterilization of tatarne as early as 1929. Scharffenberg, who played many roles during the interwar period, was from 1919 until 1940 the doctor at a state penitentiary and from 1922 was a member of the council and Head Doctor at the Oslo Hospital's mental hospital. ${ }^{307}$

The treatment of indigenous ethnic populations in Norway was handled largely through religious meso-level organizations. One group, originally known as the Norwegian Mission among the Homeless (Norsk misjon blant hjemløs, NMBH), was just such a "Christian philanthropic group." 308 This group made several assumptions; its members believed that a "mobile lifestyle" was more or less criminal and the life style itself was at least partially biologically pre-determined. In addition, the background of the group had "an association with the politics of criminality and the racial hygiene viewpoint." 309

Under the influence of the NMBH and Ingvald B. Carlsen who was the Mission's General Secretary from 1918 to 1935, the Church and Education Department issued a letter in 1904 that described taterne as both those that lived as tarterne - even if they were not ethnically so and originally were residents of a particular place - and members of the ethnic group itself. ${ }^{310}$ In contrast to this, Dr. Johann Scharffenberg maintained that the larger group of taterne was a distinct and different ethnic group. ${ }^{311}$ Many things could be said about how the Mission dealt with the taterne

306 Bjørn Hvinden, "Fra fordømmelse til respect og vergihet: Det norske samfunnets skiftende forhold til romanifolket” in Bjørn Hvinden (ed.), Romanifolket og det norske samfunnet: Følgene av hundre års politikk for en nasjonal minoritet (Bergen: Fagbokforlaget, A.S., 2000), 11.

307 Ibid., 67. He held the second position there until 1941 when, under Nazi occupation, he was removed. In 1934, at about the same time as the sterilization legislation, he was prosecuted under Norwegian law for his unflattering publically printed comments about Hitler. He was eventually acquitted of the charge on legal "technicality", in a lovely sleight of (legal) hand.

308 Per Haave, “NS-Regimets 'taterpolitikk' - en minoritetspolitikk i utakt?” in Per Ole Johansen (ed.), På Siden av Rettsoppgjøret (Oslo: Unipub Forlag, 2006), 180. “...plannen oppsto ikke i et tomrom."

309 Ibid.

310 Ibid., 182.

311 Ibid., 183. Debates about ethnicity and the taterne continued well into the $20^{\text {th }}$ century. What can be said is that some Norwegian politicians had a problematic relationship with ethnically different groups, although after the turbulence of the 1970s, much of this has changed for the better. 
but, for our purposes here, the most interesting is that this group believed itself to be doing philanthropic work for the less fortunate. In 1931, Carlson said in an informal radio lecture that:

it's the Christian feeling of responsibility (or the human feeling of solidarity) that tells us that these are human beings and we must try to give them a sense of human worth. ${ }^{312}$

But despite this, the goal of the Mission was always twofold, to gain social control over the tarterne as well as providing assistance to them. This rhetoric of care, in this case - Christian care - is not unlike the rhetoric of the progressive movement in Indiana. In many cases, the progressive movement allied itself with American churches, mostly protestant, and had identical concerns as this Mission in Norway, albeit to different minority groups.

Per Haave points out that Norway's treatment of the taterne "did not happen in an empty room." ${ }^{313}$ Aside from the factors already mentioned, it should also be remembered that during the nation-building phase of Norway's history - which was not more than a few years in the past - the concept of a "real Norwegian" was clearly connected to

more or less romantic pictures of the life style of farmers and their culture such that this became constituted and cultivated through folk museums, folk music, folk stories, farmer stories, the traditional clothing of farmers, books on farm construction and the like. ${ }^{314}$

In all of these areas, there was simply little social space - and thus very little opportunity - for the ethnic minorities mentioned above to fit into society - should they have even wanted to do so - especially if they were labeled as "transient" or "vagrant."315

312 Ibid., 185.

313 Per Haave, “NS-Regimets ‘taterpolitikk', 180. Note 510.

314 Ibid., 21.

315 The issue of vagrants includes issues of control and surveillance. On May 22, 1928, a directive was sent from the Justice Department in Oslo to all government officials and civil servants in Norway where there was a directory of births and a Church register of births, to register all the vagrants and also settled families and send this information back to both the Mission and the Central Bureau of Statistics. The goal was to create an inclusive and central registration of all vagrants. As Per Haave notes, "this never saw the light of day" but that was not for lack of effort, especially by Oslo's Police Chief Kristian Welhaven and Chief of Education Reidar Sveen. (Per Haave, "NS-Regimets 'taterpolitikk', 195. Note 510. "Sentralen så aldi dagens lys.") Welhaven was the Vice President and Norwegian Representative on the International Kriminalpolizeilichen Kommission (IKPK), the forerunner to Interpol, which was founded in Vienna in 1923. (Ibid.) This group was interested in many things but wanted a coordinated effort to stop the migration of gypsies. In 1934 there were about 5,000 to 6,000 gypsies in Norway and about 1,500 to 1,700 tarterne; Welhaven told the IKPK that the Mission would do the registration of vagrants. 


\subsection{Norwegian Welfare Institutions and Political Governance}

Why have science and the personal way of handling human troubles been introduced as a "health" program? Why have all the new methods of dealing with criminal vagrants, al- coholics, prostitutes, and other asocial persons so closely linked with the idea that these people are sick?

Vilhelm Aubert ${ }^{316}$

While Norway already had a number of institutions such as insane asylums, prisons, and hospitals, there was a need for more such facilities in 1934. All public institutions seemed to be overcrowded and underfunded, just as in Indiana in 1907. Private medical institutions were established in Norway and some doctors had a following from the middle and upper classes at these places. But even private welfare institutions were in need of funds and fund-raising became the raison d'être of some middle and upper class women's groups.

In addition, one cannot help but note the narrative emphasis on "sanity" and "insanity" in the media especially with regard to crime. Newspapers focused relentlessly on the insane and crime, not unlike Indiana in 1907.317 The two issues articulated and became what I imprecisely call the "dangerous people on the loose and possibly roaming near the reader." ${ }^{318}$ But, in point of fact, this phenomenon was part of the Pescosolido Model, discussed above. If the individual is not safely nested within a set of concentric circles - family, community, region and nation - then how do we know s/he is safe? This continued throughout 1934 in Norwegian newspapers, especially in Aftenposten.

The wandering person was basically not in the network of social life that Pescosolido described above as pre-modern. And, in Norway, where the Sámi people's way of life included wandering with their herds of reindeer, this had always been a problem. If Norwegians did not know which "gård"319 a stranger was from, what did s/he really know about the stranger? And a further - practical - question developed for the citizens of the relatively poor nation, i.e. if a wandering stranger was in need or ill, who was responsible for that person? ${ }^{320}$ In Norway, during its premodern-modern transi-

316 Vilhelm Aubert, "Legal Justice and Mental Health" in Psychiatry: Journal for the Study of Interpersonal Processes, 21 (1958), 112. Perhaps Aubert would not have written exactly these same words in the $21^{\text {st }}$ century. However, he might very well have objected to what is called the "sortering" (sorting according to various attributes) of persons in Norwegian society.

317 In fact, during the well-publicized trial of Henry Kendal Thaw, the term "dementia Americana" was used to describe the insanity of the rich and famous.

318 This discursive model was often rearranged with reference to ethnic groups, i.e. the "travelers." 319 Literally, "farm" but can mean a house or building in an urban setting.

320 In the United States, severe social responses were reserved for "strangers”, outsiders with mental illnesses who were not considered the community's responsibility. Prior to the mid-nineteenth cen- 
tion, as disease came to be perceived as an individual condition, the sterilization law addressed the issue of who was responsible. The soon-to-be-passed sterilization law was drafted so as to deal with the "residence" of the mentally ill or dangerous through the institution of the local police chief.

For example, in April 1934, newspapers carried a story of a dangerous mentally disturbed man who had escaped from the Reitgjerdet Asylum in Trondheim. ${ }^{321}$ Karl Isidor Braaten, who was 43 years old, had escaped on Holy Thursday after having been at Reitgjerdet for 10 years. His family, who lived in Hurdalen, said that he was not dangerous although the police disagreed and said he should be characterized as dangerous. ${ }^{322}$ In some cases, there were legitimate concerns for public safety. In mid-April, yet another mentally ill man tried to kill his wife, his seven-year-old son, and himself in Drammen. ${ }^{323}$ As the Pescosolido model's diagrammatic explanation of societal transition demonstrates, the movement from concentric "nested" social networks to "overlapping [and] intersecting social circles" caused the individual to became the center of the etiology of "insanity" and the home or the community were "contaminated." It was thought that this left few options except to confine the insane in "well-ordered asylums" elsewhere that reflected the "demarcation" of these social circles "by socio-demographic characteristics...differentiated...by race, class and status of education, and private hospitals appeared for the affluent." ${ }^{24}$

Reporting on criminal law problems was a regular feature of Oslo newspapers and the first few days of May illustrate this point. On 3 May on the front page of the afternoon edition, Aftenposten asked if there were sexual criminals populating Steenstrups gate saying there had been a suspect arrested there the previous day. ${ }^{325}$ On 7 May, crime statistics were printed saying that for every 400 adults in Oslo there was one lawbreaker and women were one-tenth of that number. ${ }^{326}$ The population of Oslo in 1934 was 266,344; 118,540 men and 147,990 women. This would have given a criminal population of around 665 men and 66 women whom the newspaper named as "criminals" distributed somehow in the public space. Within the space of 5 days,

tury "[t]he policy of "warning out" allowed towns to return individuals with mental illnesses to the towns where they held legal residence." Please see, Bernice A. Pescosolido-Rubin and Beth A. Rubin, "The Web of Group Affiliations Revisited: Social Life, Postmodernism, and Sociology" in American Sociological Review, 65 (2000), 67.

321 Aftenposten (p.m. Edition), April 3, 1934, 1.

322 Ibid.

323 Aftenposten (p.m. Edition), April 14, 1934, 1. Directly adjacent to the Karl Braaten story in this newspaper was yet another story of insanity that had not yet had the time to unfold before the country or the world. The headline read: "Hitler i Norge i Sogn og Hardanger ombord på panserskibet "Deutschland."

324 Pescosolido-Rubin and Rubin, “The Web of Group Affiliations”, 67.

325 Aftenposten (p.m. Edition), May 3, 1934, 1.

326 Aftenposten (p.m. Edition), May 7, 1934, 5. 
the reading public in Oslo and throughout Norway for that matter, had been exposed to a story written about the possibility of sexual criminals within a certain area of Oslo and then the scientific verification that at least some persons in that area were criminals.

About a week after the suggestion that sexual criminals inhabited Steenstrup gate, Aftenposten carried a feature article by Dr. hr. Hospital Director Henrik A. Th. Dedichen (b. 1895) entitled "The Punishment and the Punished." ${ }^{327}$ Dedichen, who had his own private psychiatric clinic in East Aker in 1934, made use of this editorial platform to comment on the use of punishment as a "weapon" that society had to protect itself from criminals. ${ }^{328}$ Dedichen commented that punishment was viewed with an increasing "distrust" and that Polish and Italian laws were being looked at with interest in "some circles." As was the customary expository style in 1934, Dedichen went back to the laws of Hammarabi to make his point which was that laws were relative to time and place and it was "simplistic ignorance" to believe that jails "pampered" law breakers. Conditions in jails should only be "as tolerable as possible."

Roughly ten days after Dedichen's editorial, Ranke Samuelsen from Trondheim also wrote a feature article entitled "Our Criminally Insane." ${ }^{329}$ In a rather sympathetic article, Samuelsen describes the asylums for the criminally insane in the midtTrøndelag region. Trondheim and Strinda had the "dubious honor" of housing the entire male criminally insane incarcerated population from throughout Norway in 1934. They were either in the criminal asylum in Kongensgate or a half hour from the city at Reitgjerdet. ${ }^{330}$ Both institutions had the same director, supervising doctor and administrative unit. ${ }^{331}$ Samuelsen was disturbed by the conditions at both places and the transfer of especially dangerous patients from other institutions in Norway to Trondheim, and most especially those with a "tendency to escape." 332 The housing together of the mentally ill, the developmentally delayed and the dangerous criminally insane was not the best of situations and a very serious problem according to Samuelson. ${ }^{333}$

The old Kongensgate asylum in Trondheim was built to hold 36 inmates and Reitgjerdet was built with 135 beds although some patients were housed in private care

327 Aftenposten (a.m. Edition), June 9, 1934, 2.

328 The west side of Oslo was more affluent than the east side of Oslo. Accents differ and the social status conferred by a westerly address remains to this day. One cannot help but notice the similarities to mid-1980s America and its sexual abuse hysteria.

329 Aftenposten, (a.m. Edition), June 20, 1934, 2.

330 Reitgjerdet continues to be used as a psychiatric institution to this day and in Case Two we also find an escape incident from the same institution. However, at that point the mentally ill population has changed from a "weak we" to a "stronger we."

331 Ibid.

332 Ibid.

333 Ibid. 
in the area. Both institutions were full. Reitgjerdet was especially a problem since whatever its construction - patients did escape. But this phenomenon, in Samuelsen's opinion was "screamed about so often and foolishly in the press." Samuelsen defended the patients at Reitgjerdet noting that they held jobs and should not be seen as criminals. Both Dedichen and Samuelsen are indicative of the progressive attitudes towards institutionalization that were present in Norway at this time and they are similar to ideas circulating in the progressive movement the case of Indiana in 1907. While Norway's progressive movement was less likely to use the term "progressive”, it certainly had a great deal of similarity to that movement in Indiana in 1907.

Not everyone agreed with Dedichen and his views on prison conditions. Appellate attorney Håkon Benneche of Stavanger took Dedichen to task, berating Dedichen for laying a "confusion of ideas" before the public. Benneche said that Dedichen's ideas were "no longer modern and would luckily disappear ...soon...along with the soft, sweet sophomoric mentality which has exhausted Europe since [1800]..."334 Benneche argued that most criminals were not mentally ill and were, in fact, "normal" individuals. On 18 July, Frants Faye Kaltenborn (b. 1901), an assistant chief of police in Oslo, became involved in the semantic fray and countered Benneche with information Kaltenborn had obtained from the Wieneruniversitets Kriminalistiske Institutt. Kaltenborn cited extensively to work done at this Institute, the Department of Criminal Law and Criminology, in his article. ${ }^{335}$ Kaltenborn maintained that other factors, including family genetic traits played a roll in criminality. ${ }^{336}$

Here we see frame bridging between the discourses of those reacting against the progressive movement with those in the eugenics movement. The progressive movement was a convenient meeting point for those inclined to left wing politics - obviously - but it also attracted right wing advocates. As the eugenics movement matured, it is easier to see how individual motivation seemed to matter more than principled thinking or argumentation.

\subsection{Norm Production at the Shifting Intersections of the Jasanoff Fields}

Just as I did with the Indiana half of this case, I now present two examples of the shifting articulations among the Jasanoff fields of knowledge co-production. They reflect,

334 Aftenposten (a.m. Edition), July 12, 1934, 2.

335 Wenzeslaus Gleispach (1876-1944) founded the institute in Vienna.

336 Aftenposten (a.m. Edition), July 12, 1934, 2. Kaltenborn was trained as a sorenskriver before becoming a police officer. From 1941-1943, he worked as the secretary of Norsk Hydro and from 1943-1945; he was the "sjef" of the "Rikspolitikorpset" in Sweden. 
I propose, the micro-subjective level of the Rickert Model and the "preconceptual/ precognitive" (ISLL) level of legal norm formation from the Tuori Model.

Individual professionals who espoused eugenics in its many formulations were often seen in the pages of Oslo's major newspapers, just as in Indiana. One such doctor, Dr. med. Sofus Widerøe, jumped on what seemed to be a fast-moving legal train in 1934 with a book review of "The Law Relating to the Genetically Ill” authored by Gütt, Rüdin and Rüttke. ${ }^{337}$ Rüdin has already been mentioned above in reference to the International Society for Race Hygiene. Widerøe's book review presented no new arguments and began with the "economics" of the mentally ill, developmentally delayed and persons with genetic illnesses. Whether or not the numbers of such people in society were actually rising, his perception was that the numbers were steadily increasing. The unique aspect of Widerøe's review was that, for the first time in 1934 in this venue, he used the language of "productivity." He asked, "Do the productive [members in] society have the ability, out of their possible profits, to afford the sum total of these individuals..." 338 Acknowledging that this is a difficult question that had faced Norway for some time, he said, candidly, "It is so difficult and yet so simple!."339

Dr. Widerøe asked a series of questions, more routinely situated in the political and legal setting. What were the rights of the individual in relation to the rights of the state? Does the genetically defective person have the right to transmit his sickness or his defective genes to another? Does the state have the right to interfere in the individual's liberty in order to stop the transmission of defective genes and/or genetic illnesses? He then quoted $\S 1$ of the German Reichsgesetzblatt I.S. 529 in which 8 conditions of genetic illness are set out and to which that law applied. ${ }^{340}$ For Widerøe, this law introduced "a new time" and it was a sign of "a new epoch"; he quoted Mein Kampf concerning those who are not "mentally or physicially sound" and pronounces the logic in Hitler's tract as in "order." ${ }^{341}$ Dr. Widerøe opined that the German law and its consequences were logically well founded and built on legal principles of the

337 Aftenposten (a.m. Edition), June 22, 1934, 2. “Gesetz zur Verhütung erbkranken Nachwunches vom 14 juli 1933” Widerøe’s 1910 PhD dissertation at the University of Oslo (Christiania) had been entitled "Die Massenverhältnisse des Herzens unter pathologischen Zustände” ("Conditions of the Heart Under Pathological Conditions”). Rüdin is mentioned numerous times throughout this dissertation in various connections with the eugenics movement. Lehman Publishing Company in Munich, which had a direct connection with Darré and the Nordic Ring, published the book that Widerøe reviewed.

338 Ibid. (Emphasis mine.)

339 Ibid.

340 Ibid. They are "1.) born as an "idiot” (with IQ less than 20), which had a specific scientific meaning at this time, 2) schizophrenic, 3.) manic-depressive illness 4.) hereditary epilespy, 5.) hereditary Huntingdons choria), 6.) born blind, 7.) born deaf, 8. born with considerable bodily malformation and chronic alcoholism. Professors Lexer and Døderlein of Munich wrote a chapter in the book on these conditions.

341 Ibid. 
state. The law was concise and medically and biologically correct; however, Widerøe conceded there would be difficulties in carrying it out. ${ }^{342}$

At one end of eugenic continuum were some enthusiasts who inevitably considered the issue of euthanasia. Again, it was Widerøe who, in August 1934, continued to promote his ideas in another "thought-piece", drawing his inspiration from a rather diverse group of people including Diogenes, Bacon and Somerset Maughum. He cited the history of euthanasia in modern times, including a 1906 legislative proposal in Ohio to allow it. Widerøe asserted that, "euthanasia has been practiced here for a hundred years by all right-minded and medical practitioners [adhering to his Hippocratic Oath]." ${ }^{343}$ Clearly, Dr. Widerøe had a rather complete societal picture and of what social policies should be in place to bring this about.

It was within acceptable schemas for an upper-class woman in 1934 to leave the boundaries of the home - if her work were charitable. ${ }^{344}$ This allowed for the building of networks, which, in turn, helped to create SMOs, as well as creating culturally pluralistic framing of issues that affected women. Upper and middle class women in Norway at this time were organized into many service groups within several social and religious arenas and September 1934 saw a number of women's national organizations begin and adjourn, one after the other. Between the $11^{\text {th }}$ and the 21 st of September 1934, five major women's groups met in Oslo - Norske Sanitetsforening (Norwegian Hygiene Association, NSF), Norske kvinners nasjonalråd (Norwegian Women's Advisory Association, NKNR), Hjemmenes Vel (Good Homes, HV), Norske kvinnesaksforening (Norwegian Women's Legal Association, NKSF) and Norges Husmorforbund (Norwegian Housewives' Association, NHMF). One of these powerful organizations - the NSF - gathered in Oslo on 11 September for its district meeting

342 Ibid.

343 Afternposten (a.m. Edition), August 17, 1934, 2. To be fair, states attorney Kjerschow rebutted Widerøe's article later on 22 August. (Aftenposten (a.m. Edition), 22 August 1934, p. 2.) (Kjerschow had been a member of the committee that did earlier prepatory work on the 1934 sterilization law for the Storting.) He noted that $\$ 235$ of the current criminal law, in the section on "Crimes against life, the body and health”, included the following paragraph:

In some cases where one's own death is consensual or the occasion or opportunity of significant bodily harm or damage to health has some measure of compassion in a hopeless life of sickness, the punishment can be reduced to a level under that which is normally applied to a less serious level.

(Ibid.) Kjerschow wrote that the criminal law still considered euthanasia as murder but that the Court issuing a punishment has access to milder sentences in some situations and that some doctors treated these situations under "unwritten law.” Obviously, Kjerschow did not agree with Widerøe, however, that a new law is needed on the subject.

344 Working class women used the worker's associations of their husbands in much the same way. The Arbeiderbladet had a Women's Section every Thursday devoted to the political, educational and charitable activities of women. 
which brought no less that around 350 women to that meeting. ${ }^{345}$ The NSF was otherwise known as the "Gray Ladies", an auxiliary of the Red Cross, whose members offered nonprofessional help to the sick and helped with hygiene education as well as raising money. Professor Olav Hanssen provided a lecture on "Food which Cures..." for the women. ${ }^{346}$

On the second day of the NSF meeting, Dr. Hanssen gave a lecture entitled "Cooperation Between the Kitchen and Doctors at the Hospital." Women attending the conference also discussed how and when to use the money that they had collected. During discussions, which included various doctors and administrators, several questions were asked and, when taken together with other indications, indicated that social schemas were indeed changing. Lina Sørensen noted that there were no dentists available in tuberculosis asylums. In addition, Lulli Lous asked the district doctor why there were no women on the Board of Directors for the Aker Doctors Hospital. The Chairwoman of the meeting, Fru Grundtvig was then moved by this iquestion to remark "We see this again and again that there is no use for women [in the NSF] other than to collect money." 347

Two days after the NSF opened its meeting in Oslo, the Norwegian National Women's Association (NKF) opened its national meeting under the direction of foreman Betzy Kjelsberg (1866-1950). ${ }^{348}$ One cannot help but speculate that this was not a coincidence as members of one organization may have been active in the other. Lorange, Grundt, Kjelsberg, Høe, Sparre, Haslund, Engebrethsen, Holmbie and Lie debated the pros and cons of the impending European war indicating that these women were prepared to debate matters of national and world importance. The next afternoon, at Hjemmenes Vel (1898-1979), the theme of women's right to work was taken up in an introduction by Kjelsberg. She reported that the danger of women losing their right to work, especially after marriage, had been discussed at the International Women's Organization Congress in Paris during that same summer. ${ }^{349}$

345 “Sanitetsforening.” Aftenposten (p.m. Edition), September 11, 1934, 2. The organization was under the leadership of Anna Dahl and Fru Mathilde Kierulf.

346 Aftenposten (p.m. Edition), September 11, 1934, 2.

347 Aftenposten (a.m. Edition) September 12, 1934, 5.

348 Aftenposten (p. m. Edition), September 13, 1934, 1. Norske kvinners nasjonal råd is abbreviated “NKNR.” “Norske kvinnersnasjonaldråd åpner sitt årsmøte.” Kjelsberg was already a member from the establishment of the NKN in 1904 and became its leader from 1922-1938, sixteen years. Kjelsberg was no stranger to leadership roles and to organizing. In 1884 she was one of the founders of the Norsk Kvindesagssforening. She founded the Kvinnelig handelsstands Forening and the Drammen Sanitetsforening in 1894, tge Drammen Kvinnesaksforening in 1896 and the Drammen Kvinneråd in 1903. In addition to this impressive list, she was the first the first female manufacturing inspector ("fabrikkinspectør") from 1910-1936. She was the first female member of the Venstre (Liberal) party and was also a Vice-Chairwoman ("viseformann") of the International Council of Women.

349 Det internasjonale kvinnersråd kongress. 
The Swedish female manufacturing inspector, Kjerstin Hesselgren, expressed the opinion that civilization itself was in danger if women lost the right of self determination, and,

also here in Norway, the woman must be wakened and be on guard. And it is necessary to use the right to vote in this manner; that women do not vote for someone other than themselves, for those who believe in the same right to work for women as for men. ${ }^{350}$

These groups were not the only ones that were debating the right of women to work after marriage. The Norsk kvinnersaksforening (Norwegian women's legal association, NKSF) was formed in 1884 and in 1934 celebrated its $50^{\text {th }}$ anniversary. ${ }^{351}$ The four persons who had led the group since its inception were Anna Stang, Hagbard Berner, Ragna Neilsen and Anne Bugge. Aftenposten reported on 15 September 1934 that this group was of the opinion that:

Norwegian women now have, in theory, full equality with men in society. In practice, however, this equality is not fully carried out. Until this is accomplished, the Norwegian Feminist Association's job is not finished. ${ }^{352}$

A leader of this group, Anna Stang, was the woman Lektor ${ }^{353}$ Harald Amundsen complained of above, in the same breath as modern psychology and birth control.

The NHMF also had a leadership course in Oslo, the same day as the celebration of the $50^{\text {th }}$ anniversary of the NKSF. ${ }^{354}$ Relations seemed to have been friendly between the two groups, on the surface at the very least. Flowers had been sent to the NKSF from a number of groups including Kjelsberg's NKR, the NSF's governing board, from Altern's Oslo Kvinneråd, the Oslo Women's Business Group, and from the Feminist Association of Drammen. ${ }^{355}$

An example of the work done by the Oslo branch of the NSF was reported the next day in Aftenposten. A sanatorium had been started at Grefsen in 1858 and from 1898 until 1909 it was privately administered as a tuberculosis facility. ${ }^{356}$ But in 1909, the NSF had assumed full control of the facility as a People's Sanatorium. Largely through its excellent organization and the force of some personalities, it raised much money for the building and maintenance of hospitals and sanitariums and was an active participant in the issues of the day that affected women and children. For example, on

350 Aftenposten (a. m. Edition), September 15, 1934, 6.

351 "Norsk kvinnesaksforening 1884-1934." Aftenposten (a. m. Edition), September 15, 1934, 7.

352 Ibid.

353 There is no equivalent in the American university system but "lecturer" is close.

354 "Husmorsforbundet"Aftenposten (p. m. Edition), September 17, 1934, 2 and 4.

355 Aftenposten (p.m. Edition), September 17, 1934, 4. Frøken Fredrikke Mørck had assumed the editorship of "Nylæende" after the death of Gina Krog.

356 Aftenposten (p.m. Edition), September 18, 1934, 5. 
3 May the Oslo NSF noted the beginning of a new facility in the autumn because the hospital that was to serve rheumatic sicknesses had been temporarily postponed. ${ }^{357}$

On the $19^{\text {th }}$ of September, the NHMF began its national meeting with and address by Michelet on the mission of the organization. Aftenposten was clearly favorably disposed to this group in the person of Michelet. She was presented as a woman who had "good and wise advice" who understood that her "fight was also for the ethical values in human life." ${ }^{358}$ Nothing so glowing had been written about women involved in the fight to change abortion laws in Norway at this time. The picture one receives of Michelet is of a woman who could charm yet could talk forcefully about women's rights. The reporter wrote that Michelet was asked a question about women's rights and answered:

that she, on the whole, believes women must be considered when we think of the national economy and no longer merely as an appendix in the category titled "women and children", she answered with a smile. ${ }^{359}$

Not only the newspaper but also the royal family seems to have been friendly with Michelet. The next day, HRH crown prince Harald of Norway, made an appearance at the NHMF's meeting. Around 300 members met in Oslo and began with the organization of committees and elections. Elected Vice Chair was Amalie Øvergaards and Betzy Kjelsberg personally gave greetings from the NKR before Michelet gave her opening address. The organization then entered "into lively debate" in which the countryside members were pitted against the city member over an issue of the Board of Governors composition. The following day at the NHMF convention was taken up with discussions of Norwegian wool and foods native to Norway. The new Chair was also chosen; Amalie Øvergaard won with a decisive majority against Wiborg Thune and Schnitzler. ${ }^{360}$

The above networking among women who had both money, time and influence is important since we see the discourses that were important to them at this time and place as well as the work they did within Norwegian society, acknowledged or not. We heard Grundtvig complain that there was no use for women in the NSF "other than to collect money" and we also read the statement issued by the NKSF that although women in Norway had equality, it was a restricted equality that was "not fully carried out" in practice. We can only guess at the private conversations these women had but the discourse of dissatisfaction was alive and well in 1934 among these associations and policy entrepreneurs.

357 “Revmatiske sygdommer.” Aftenposten (a.m. Edition), May 3, $1934,7$.

358 Aftenposten (a.m. Edition), September 19, 1934, 7.

359 Aftenposten (a.m. Edition), September 19, 1934, 7.

360 Aftenposten (a.m. Edition), September 21, 1934, 5 and 7. 